\title{
Phenolic Compounds Isolated from Olive Oil as Nutraceutical Tools for the Prevention and Management of Cancer and Cardiovascular Diseases
}

\author{
Patricia Reboredo-Rodríguez ${ }^{1,2,+}$, Alfonso Varela-López ${ }^{1,+}$, Tamara Y. Forbes-Hernández ${ }^{1}$ (D), \\ Massimiliano Gasparrini ${ }^{1}$ (1), Sadia Afrin ${ }^{1}{ }^{(1)}$, Danila Cianciosi ${ }^{1}$, Jiaojiao Zhang ${ }^{1}$, \\ Piera Pia Manna ${ }^{1}$, Stefano Bompadre ${ }^{3}$, José L. Quiles ${ }^{4}$ (D), Maurizio Battino ${ }^{1, *}$ (i) \\ and Francesca Giampieri ${ }^{1, *}$ (i) \\ 1 Dipartimento di Scienze Cliniche Specialistiche ed Odontostomatologiche (DISCO)-Sez. Biochimica, \\ Facoltà di Medicina, Università Politecnica delle Marche, 60131 Ancona, Italy; preboredo@uvigo.es (P.R.-R.); \\ avarelalopez@gmail.com (A.V.-L.); tamara.forbe@gmail.com (T.Y.F.-H.); m.gasparrini@univpm.it (M.G.); \\ dolla.bihs@gmail.com (S.A.); danila.cianciosi@gmail.com (D.C.); zh.jojo@yahoo.com (J.Z.); \\ p.piera@hotmail.it (P.P.M.) \\ 2 Departamento de Química Analítica y Alimentaria, Grupo de Nutrición y Bromatología, \\ Universidade de Vigo, 32004 Ourense, Spain \\ 3 Dipartimento di Scienze Biomediche e Sanità Pubblica, Università Politecnica delle Marche, 60131 Ancona, \\ Italy; s.bompadre@univpm.it \\ 4 Department of Physiology, Institute of Nutrition and Food Technology "José Mataix", \\ Biomedical Research Center, University of Granada, Avda del Conocimiento sn., 18100 Armilla, Granada, \\ Spain; jlquiles@ugr.es \\ * Correspondence: m.a.battino@univpm.it (M.B.); f.giampieri@univpm.it (F.G.); Tel.: +39-071-220-4646 (M.B.); \\ +39-071-220-4136 (F.G.); Fax: +39-071-220-4123 (M.B. \& F.G.) \\ + These authors have contributed equally to this work.
}

Received: 1 July 2018; Accepted: 4 August 2018; Published: 6 August 2018

\begin{abstract}
Non-communicable diseases (NCDs) have become the largest contributor to worldwide morbidity and mortality. Among them, cancer and cardiovascular diseases (CVDs) are responsible for a $47 \%$ of worldwide mortality. In general, preventive approaches modifying lifestyle are more cost-effective than treatments after disease onset. In this sense, a healthy diet could help a range of NCDs, such as cancer and CVDs. Traditional Mediterranean Diet (MD) is associated by the low-prevalence of certain types of cancers and CVDs, where olive oil plays an important role. In fact, different epidemiological studies suggest that olive oil consumption prevents some cancers, as well as coronary heart diseases and stroke incidence and mortality. Historically, the beneficial health effects of virgin olive oil (VOO) intake were first attributed to the high concentration of monounsaturated fatty acids. Nowadays, many studies indicate that phenolic compounds contained in olive oil have positive effects on different biomarkers related to health. Among them, phenolic compounds would be partially responsible for health benefits. The present work aims to explore, in studies published during the last five years, the effects of the main phenolic compounds isolated from olive oil on different cancer or CVD aspects, in order to clarify which compounds have more potential to be used as nutraceuticals with preventive or even therapeutic properties.
\end{abstract}

Keywords: olive oil; bioactive compounds; cancer; cardiovascular diseases; prevention; Mediterranean Diet

\section{Introduction}

Nowadays, Non-communicable diseases (NCDs) have become the largest contributor to worldwide morbidity and mortality even in low- and middle-income countries, causing 17 million 
of premature deaths (under the age of 70) [1]. Among them, cancer and cardiovascular diseases (CVDs) are responsible for a $47 \%$ of worldwide mortality. In 2015, overall age-standardized cancer incidence rates were 205 and 165 cases per 100,000 person-years in men and women, respectively, being responsible for a $16 \%$ of global deaths [1]. Regarding the type of cancer or organ affected, the five most common types of cancer causing death in 2015 were (in the order of frequency) lung, liver, stomach, colorectal and prostate cancers in men, whereas in women were breast, lung, colorectal, cervical and stomach cancers [1]. In addition, economic impact of cancer is significant and is increasing. It has been estimated that the total annual economic cost of cancer was approximately US\$2.5 trillion in 2015 [2].

Notwithstanding, the first cause of death globally are CVDs, a group of disorders affecting heart and blood vessels that represent $31 \%$ of all global deaths in 2015 [1] including coronary heart disease (CHD), cerebrovascular disease, peripheral arterial disease, pulmonary embolism, rheumatic heart disease, and congenital heart disease and deep vein thrombosis. All these disorders are commonly caused by build-up of fatty deposits on the inner walls of the blood vessels that supply the heart, brain, or even arms and legs, causing a blockage that prevents blood from flowing to these organs. Strokes can also be caused by bleeding from a blood vessel in the brain or from blood clots. Among CVD-caused deaths, an estimated 7.4 million were due to CHD and 6.7 million were due to strokes. In addition, the risk of suffering this event is increased by other disorders that could be named as "intermediate risks factors", such as hyperlipidemia, hypertension, diabetes, overweight and obesity. CVDs place a heavy burden on the economies of low- and middle-income countries, but they also contribute to poverty at the household level due to catastrophic health spending and high out-of-pocket expenditure.

It has been estimated that between 30 and 50\% of cancers [3], as well as most CVDs, are largest preventable by healthy lifestyle choices. Both pathologies share behavioral risk factors, such as tobacco use, unhealthy diet and obesity, physical inactivity and harmful use of alcohol that could be addressed using population-wide strategies to reduce mortality and morbidity associated $[4,5]$. Changes in these behavioral risk factors may lead to the improvement of intermediate risk factors (blood pressure, blood glucose, blood lipids, overweight and obesity). In general, preventive approaches to modifying lifestyle are more cost-effective than treatments after disease appears. Therefore, consuming a healthy diet throughout the life course can help to prevent a range of NCDs, such as cancer and CVDs. Although healthy diet features depend on individual features (e.g., age, gender and lifestyle), available foods, dietary customs, and even cultural context, some basic principles of what constitute a healthy diet have been established. During the adult stage, a healthy diet should contain vegetables, fruits, legumes, whole grains and nuts [6], less than $10 \%$ and $30 \%$ of total energy intake from free sugars and fats, respectively [6-8], as well as less than $5 \mathrm{~g}$ of salt per day. Concerning fat, unsaturated fats are preferable to saturated fats [7] and trans-fats should be reduced to less than $1 \%$ of total energy intake [6,7]. This is supported by the low-prevalence found for some NCDs including certain types of cancers and CVDs in countries from the Mediterranean region in comparison to the other parts of the world [9-14]. A similar association of adherence to a Mediterranean Diet (MD) with cancer mortality, risk of several cancer types [15], and CVD incidence and its associated mortality have been reported [15,16].

\section{Olive Oil and Phenolic Compounds}

Traditional MD is characterized by high intake of cereals, vegetables, fruits, nuts, legumes, low intake of meat and meat products, a moderate intake of fish and seafood and a modest consumption of alcohol [17], accompanied by a regular intake of olive oil (OO), mainly virgin $\mathrm{OO}$ (VOO) or extra virgin $\mathrm{OO}$ (EVOO), of which consumption typically ranges between 25 and $50 \mathrm{~mL}$ (approximately two tablespoons) per day $[18,19]$. Actually, different authors have stated the NCDs lowered incidences to OO intake, at least in part. Different epidemiological studies suggested that OO consumption is implicated in preventing certain cancers, with the most promising findings for breast and many digestive tract cancers [12,20-24], as well as CHD and stroke mortality and incidence [25-29]. The suggested OO's benefits on cardiovascular health and CVD risk factors are supported by strong mechanistic evidence from experimental studies [30-33]. 
EVOO and VOO come mostly from the mesocarp (epicarp and fleshy mesocarp, approximately $95 \%$ ) with a small contribution from the seed of the fruit (endosperm and embryo, approximately $5 \%$ ), after first and second pressings of the olive fruit by a cold-pressing method, where no chemicals and only a small amount of heat are applied [34,35]. OO is a complex mixture of over 200 compounds, of which composition depends on many factors, including geographical origin, weather and irrigation, ripening and processing after harvesting [36]. The main constituents of $\mathrm{OO}$ are triglycerides, the so-called saponifiable fraction (98-99\%). The main fatty acids in the triglyceride fraction are a monounsaturated fatty acid (oleic acid, 55-83\%), a saturated fatty acid (palmitic acid, 7.5-20\%) and a polyunsaturated fatty acid (linoleic acid, 2.5-21\%) [37-39]. The remaining unsaponifiable fraction (1-2\%) contains (i) lipophilic phenols (tocopherols), (ii) sterols, the main sterol being beta-sitosterol, (iii) color pigments, mainly chlorophylls and carotenoids (the most important is beta-carotene), (iv) alcohols, (v) waxes, aldehydes, esters, ketones and (vi) phenolic compounds (hydrophilic phenols) [36].

Historically, the beneficial health effects of VOO intake were first attributed to the high concentration of monounsaturated fatty acids $[18,35]$. Oleic acid showed its ability to protect against cardiovascular events, ameliorate insulin resistance, improve endothelial dysfunction and inflammation, and reduce proliferation and apoptosis in vascular smooth muscle cells (VSMCs), compared with saturated fatty acids, such as palmitic acid. Such effects would be possibly triggered via the inhibition of JNK-1/2 and NF- $\mathrm{KB}$ pathways, at least in part [40]. These activities may contribute to an ameliorated atherosclerotic process and its stability in vivo. After that, studies performed thus far have demonstrated that $\mathrm{OO}$ phenolic compounds have positive effects on various physiological biomarkers, implicating phenolic compounds as partially responsible for health benefits associated with the MD, including anti-microbial, anti-oxidant and anti-inflammatory activities [11,13,23,41-45].

In VOO, the main classes of phenols are phenolic acids, phenolic alcohols, flavonoids, secoiridoids and lignans. Secoiridoids present elenolic acid (EA) or its derivative forms in their molecules and usually appear as aglycon derivatives. The most abundant secoiridoids in VOO are: (i) the dialdehydic form of decarboxymethyl-EA linked to hydroxytyrosol (HT) or tyrosol (Tyr) (3,4-DHPEA-EDA and p-HPEA-EDA, respectively), (ii) an isomer of oleuropein (OLE) aglycone (3,4-DHPEA-EA) and (iii) the ligstroside aglycone (p-HPEA-EA). These aglycone derivatives of secoiridoid glucosides are mostly originated during mechanical extraction process of oil, as a consequence of oleuropein (OLE) hydrolysis, as well as of demethyloleuropein, and ligstroside owing to endogenous $\beta$-glucosidases [37]. The absolute concentration of phenols in $\mathrm{OO}$ is the result of a complex interaction between several factors, including cultivar, degree of maturation, climate and other agronomic and technological factors, such as the extraction procedures [46-52].

Nowadays, EVOO can be promoted for its important health-promoting properties [53-55], mostly attributable to its content in polyphenols and well-known for their antioxidant power. In support of this, an important claim by the European Food Safety Authority (EFSA) was released in 2011, based on several scientific investigations concerning the role of phenols in human health [56]. Based on EFSA opinion, European Community Regulation 432/2012 [57] reported, among others, the health claim for OO polyphenols "olive oil polyphenols contribute to the protection of blood lipids from oxidative stress" that only can be used for OOs which contain at least $5 \mathrm{mg}$ of HT and its derivatives (e.g., oleuropein complex and Tyr) per $20 \mathrm{~g}$ of $\mathrm{OO}$.

Recognized properties of polyphenols from OO make this compound an optimal candidate to be used as a nutraceutical. This term has been defined by Defelice [58] as "a food or parts of food that provide medical or health benefits, including the prevention and/or treatment of disease". Nutraceutical properties of foods have attracted attention from agri-food sector [59]. Several agricultural products have been found to naturally present healthy components in numerous studies. To date, more than 36 phenolic compounds have been isolated from EVOO and identified, although they are present at very different concentrations $(0.02-600 \mathrm{mg} / \mathrm{kg})$ [45]. Most of phenolic compounds 
from $\mathrm{OO}$ have been shown to be highly bioavailable, reinforcing their potential health-promoting properties [60-62].

The bioavailability of OO phenolics has been determined by measuring the concentration of the phenolic compounds and their metabolites in biological fluids, mainly plasma and urine, after ingestion of pure compounds or OO, either pure or enriched with the phenolics [63]. Research conducted on humans showed that HT and Tyr are dose-dependently absorbed after ingestion [60,64-66]. Vissers et al. [62] demonstrated that absorption of HT, ligstroside, oleuropein, and Tyr, was as high as $55-66 \%$. In another study, Miro-Casas et al. [67] reported that even from moderate doses $(25 \mathrm{~mL} / \mathrm{d})$, approximately $98 \%$ of HT was present in plasma and urine, mainly as glucuronide conjugates.

As a consequence of health, as well as economical and global importance of cancer and CVDs, the relationship between these diseases and OO, mainly EVOO or VOO, has become very important nowadays. The present work aims to explore the effects of the main phenolic compounds isolated from $\mathrm{OO}$ on different cancer or CVD aspects in studies published during the last five years with the intention to clarify which compounds have more potential to be used as nutraceuticals with preventive or even therapeutic properties. Alternatively, some of these compounds could also be added or potentiated in some food industry products yielding new functional foods.

\subsection{Hydroxytyrosol and Derivatives}

HT is a phenyl ethyl alcohol, mainly generated during storage of VOO as a consequence of hydrolytic mechanisms that release it from other complex phenols as secoiridoids [68,69]. The amount of HT that could be formed during VOO storage depends on the storage temperature, as well as on the initial concentration of the complex forms (ranging from $8.4 \mu \mathrm{mol} / \mathrm{kg}$ to $65 \mu \mathrm{mol} / \mathrm{kg}$ after 18 months at $25{ }^{\circ} \mathrm{C}$ in El Hor and Chetoui OOs, respectively) [70]. Anti-tumor activity of HT has been evidenced by several in vitro studies. In the last five years, it has been reported that treatments with HT exerted anti-proliferative effects on DLD1 human colon cells [71], TFK-1 and KMBC human cholangiocarcinoma cells and GBS-SD human gallbladder cancer cells [72] and hepatocellular carcinoma cells (HepG2, Hep3B, SK-HEP-1 and Huh-7) [73], as well as on breast (MDA and MCF-7), prostate (LNCap and PC3) and colon (SW480 and HCT116) cancer cell lines [74]. However, the magnitude of these anti-proliferative effects have been reported to depend on cell type; one of the studies on prostate cancer cells showed more resistance to growth inhibition respect than breast and colon cancer cells [74]. Anti-tumor effects of HT could also reside in its reported capacity to reduce cell viability and/or promote apoptotic cell death on human cholangiocarcinoma (TFK-1 and KMBC) [72], colon cancer (DLD1) [71], gallbladder cancer (GBS-SD) [72], hepatocellular carcinoma (HepG2, Hep3B, SK-HEP-1 and Huh-7) [73] and papillary (TPC-1, FB-2) and follicular (WRO) thyroid cancer cells [75] (Figure 1, Table 1).

Anti-proliferative effects have been associated with an arrest of cell cycle in G2/M phase (Figure 1) in TFK-1 and KMBC human cholangiocarcinoma cells, GBS-SD human gallbladder cancer cells [72] and several hepatocellular carcinoma cells (HepG2, Hep3B, SK-HEP-1 and Huh-7) [73], which resulted in cellular apoptosis in many but not all cell types [72]. In relation with these findings, Toteda et al. [75] reported a reduction of cyclin D1 expression and an up-regulation of cell cycle key modulator p21 levels in papillary (TPC-1, FB-2) and follicular (WRO) thyroid cancer cell lines, which were associated with a decreased viability and increased apoptosis markers. Finally, López De Las Hazas et al. [76] studied the anti-proliferative and apoptotic activities of HT and its main catabolites detected in human feces (phenylacetic, phenylpropionic, hydroxyphenylpropionic, and dihydroxyphenylpropionic acids and catechol) in colon cancer cell lines (Caco-2 and HT-29). The results from this study suggested HT, phenylacetic and hydroxyphenylpropionic acids are able to block cell cycles and promote apoptosis. Caco-2 cells were more resistant to phenol treatments than HT-29 cells. On the other hand, Rosignoli et al. [74] correlated anti-proliferative activities with the $\mathrm{H}_{2} \mathrm{O}_{2}$ accumulation in breast (MDA and MCF-7), prostate (LNCap and PC3) and colon (SW480 and HCT116) cancer cell lines. Similarly, increased intracellular reactive oxygen species ROS were found in DLD1 human colon cancer after incubation with HT [71]. This suggests that HT could cause oxidative 
stress in cancer cells with subsequent cellular damage that possibly leads to cell death or, at least, to cell cycle arrest. In fact, Rosignoli et al. [74] also reported that the ability of the different cell lines to remove $\mathrm{H}_{2} \mathrm{O}_{2}$ from the culture medium was inversely correlated with their sensitivity to the anti-proliferative effect of HT. On the other hand, ROS generated after treatments with HT could act as a secondary messenger triggering or inhibiting different cellular signaling pathways. In this sense, Zhao et al. [73] found that HT suppressed activation of Akt and nuclear factor-kappa B (NF-kB) pathways in hepatocellular carcinoma cells (HepG2, Hep3B, SK-HEP-1 and Huh-7), which could be related with its negative effects on cell cycle and proliferation. In contrast, it activated the PI3K/Akt pathway leading to FOXO3a phosphorilation and then down-regulated FOXO3a's target genes in DLD1 human colon cancer cells promoting in this case a situation of oxidative stress [71]. HT could also negatively modulate the extracellular signal-regulated kinase (ERK) pathway, of which alteration towards over-activation has been usually considered as a necessary step in the development of many cancers, since time- and dose-dependent decrease of phosphorylated form of the ERK has been observed after HT treatments in human hepatocellular carcinoma cells [73]. Finally, HT can affect vascular endothelial growth factor (VEGF)-induced endothelial cell proliferation and migration, as well as their morphogenic differentiation into capillary-like tubular structures in Matrigel (in vitro angiogenesis), being one of the most potent angiogenesis inhibitor in a study comparing different compounds from EVOO. Such an effect would depend on inhibitory action on specific autophosphorylation sites of VEGF receptor-2 (VEGFR-2), leading to the inhibition of endothelial cell signaling [77].

In rats, HT has been found to inhibit tumor growth and proliferation rates in DMBA-induced breast cancer when it was administrated during 6 weeks after the treatment [78]. Results were comparable to those of doxorubicin, a chemotherapeutic agent commonly used in breast cancer treatment, and proved better with regard to the histopathological outcome. Then, Li et al. [72] observed anticancer effects of HT intraperitoneally administered on a cholangiocarcinoma mouse model, where HT markedly inhibited tumor growth. Likewise, tumor growth and angiogenesis results negatively affected by intraperitoneal HT in an orthotopic model of human hepatocellular carcinoma in mouse [73]. Despite the fact that the compound did not reach tumor cells by oral ingestion, some of the reported effects on tumors were similar to those noted in the DMBA-induced breast cancer model [78], and some of the mechanisms observed could also be present in animals receiving HT orally. Different mechanisms responsible for these activities have been reported in mentioned studies including the alteration of the expression of genes related to the apoptosis, cell cycle, proliferation, differentiation, survival and transformation pathways [78], which could be explained, at least in part, by the activation of Akt [73], NF- $\mathrm{kB}$ [73] or Wnt signaling pathway, promoting a high expression of secreted frizzled-related protein 4 [78].

Beyond anti-tumoral activities, some compounds present in EVOO could exert a preventive effect decreasing susceptibility to cancer. di Francesco et al. [79] investigated the effects of EVOO, its phenolic compounds or HT on endocannabinoid system (ECS) gene expression via epigenetic regulation in human colon cancer cells (Caco-2) exposed to dietary EVOO. They observed a selective and transient up-regulation of CNR1 gene that was evoked by exposure of Caco-2 cells to EVOO, its phenolic extracts or HT for $24 \mathrm{~h}$. None of the other major elements of the ECS was affected at any time point. The stimulatory effect of phenolic extracts and HT on cannabinoid type 1 receptor expression was inversely correlated to DNA methylation at CNR1 promoter and was associated with reduced proliferation of Caco-2 cells.

On the other hand, it was reported the attenuation of inducible nitric oxide synthase (iNOS), cyclooxygenase-2 (COX-2) and tumor necrosis factor $\alpha(\mathrm{TNF} \alpha)$ by HT in lipopolysaccharide (LPS)-challenged human monocytic THP-1 cells [80]. It has also been reported that HT possessed significant anti-inflammatory actions in an animal model of inflammation and attenuated TNF $\alpha$ and interleukin 1 beta (IL-1 $\beta$ ) expression [81]. More recently, HT at nutritionally relevant concentrations has shown to down-regulate the gene expression of adhesion molecules, chemoattractants, matrix metalloproteinases (MMPs) and proinflammatory enzymes [82,83]. 


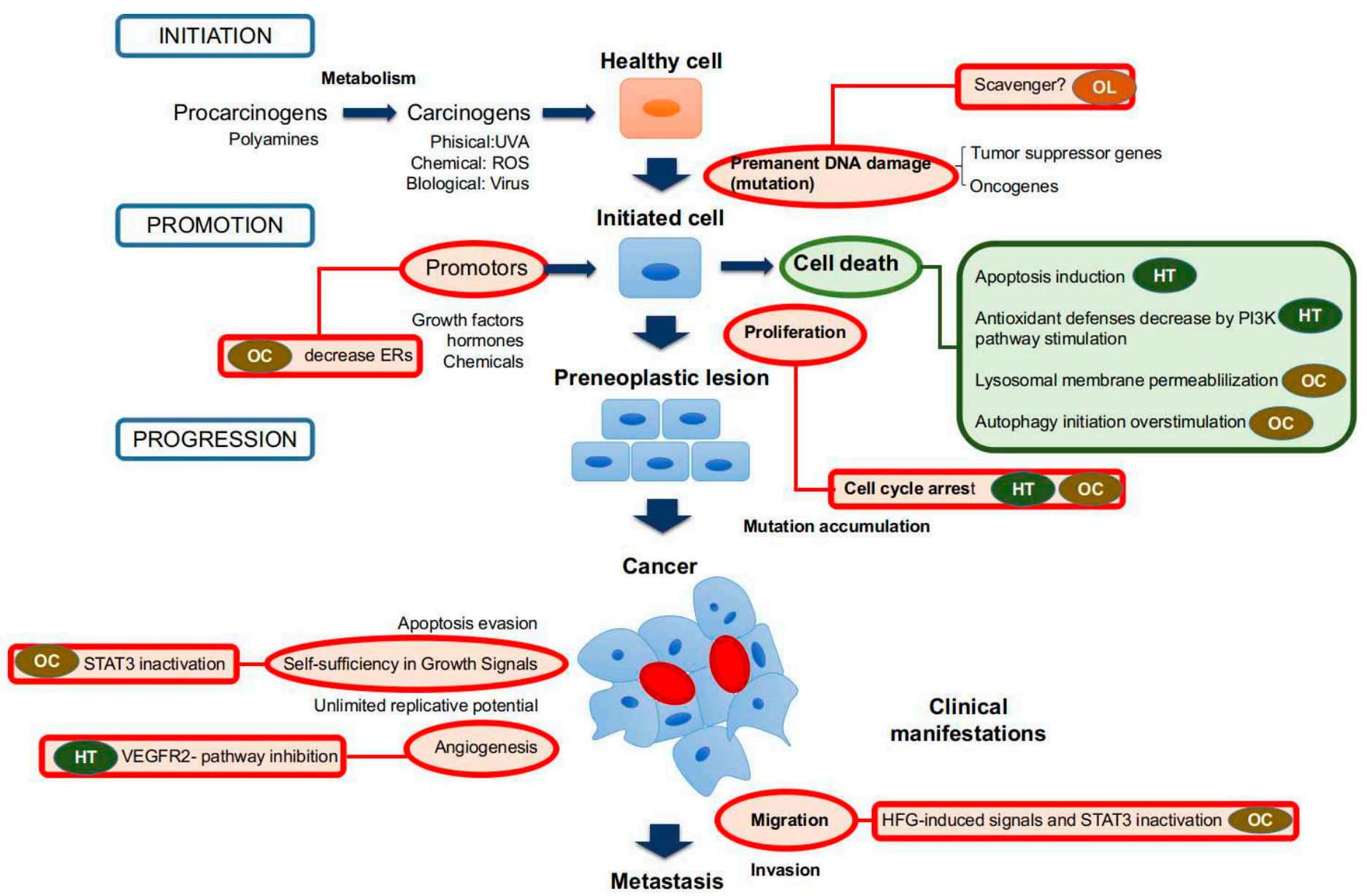

Figure 1. Anti-tumor and anti-cancer effects of main phenolic compounds found in olive oil (OO). Red circles mean inhibitory activities, and green circles mean stimulatory effects. Abbreviations: HT: hydroxytyrosol; OC: oleocanthal; OLE: oleuropein. 
Table 1. Studies on hydroxytyrosol (HT) and derivatives effects on cancer and cardiovascular diseases (CVDs) in the last five years

\begin{tabular}{|c|c|c|c|}
\hline Sample & Treatments & Main Results & Ref \\
\hline CRC adenocarcinoma cells (DLD1) & $\mathrm{HT}(0-300 \mu \mathrm{M}$ for 24 and $48 \mathrm{~h})$ & $\begin{array}{l}\text { HT induces ROS generation and leads to PI3K/Akt pathway activation, } \\
\text { decreasing the antioxidant defense capacity through FOXO3a suppression. }\end{array}$ & {$[71$} \\
\hline Human CCA (TFK-1 and KMBC) and human gallbladder (GBS-SD) cancer cells & HT $(0-200 \mu \mathrm{M}$ for 24,48 and $72 \mathrm{~h})$ & HT induces cell cycle arrest and apoptosis. & {$[72$} \\
\hline Human hepatocellular carcinoma (HepG2, Hep3B, SK-HEP-1 and Huh-7) cells & HT $(0-400 \mu \mathrm{M}$ for 48 and $72 \mathrm{~h})$ & HT can suppress the activation of Akt and NF-kB pathways. & {$[73$} \\
\hline $\begin{array}{l}\text { Human breast (MDA and MCF-7), prostate (LNCap and PC3) and colon (SW480 } \\
\text { and HCT116) cancer cells }\end{array}$ & $\begin{array}{l}\text { HT ( } 100 \mu \mathrm{M} \text { for } 24,48,72,96,120 \text { and } \\
144 \mathrm{~h})\end{array}$ & HT inhibits the proliferation of all cell lines. & {$[74$} \\
\hline Human thyroid carcinoma (TPC-1 and FB-2), papillary and follicular (WRO) cells & HT (65-973 $\mu \mathrm{M}$ for 24 and $48 \mathrm{~h})$ & $\begin{array}{l}\text { HT reduces viability in all cell lines and exerts proapoptotic effects on papillary } \\
\text { and follicular cancer cells. }\end{array}$ & {$[75$} \\
\hline Human colon cancer cells (Caco-2 and HT-29) & HT (100-200 $\mu \mathrm{M}$ for 8 and $48 \mathrm{~h})$ & HT produces cell cycle arrest and promotes apoptosis. & {$[76$} \\
\hline $\begin{array}{l}\text { Human umbilical vein endothelial cells (HUVECs) and dermal microvascular } \\
\text { endothelial cells (HMVECs-d-Ad) }\end{array}$ & $\mathrm{HT}(0-50 \mu \mathrm{M}$ for 18 and $24 \mathrm{~h})$ & HT inhibits VEGFR-2 signaling pathway. & {$[77$} \\
\hline Male nude BALB/c mice cholangiocarcinoma xenograft (6-8 weeks old) & $\begin{array}{l}\text { Intraperitoneally injected HT ( } 500 \\
\mathrm{mg} / \mathrm{kg} \text {, daily, } 3 \text { weeks after the tumor } \\
\text { volume reached } \sim 120 \mathrm{~mm}^{3} \text { ) }\end{array}$ & HT inhibits cholangiocarcinoma growth. & {$[72]$} \\
\hline Orthotopic HCC model in nude mice cholangiocarcinoma xenograf ( $4-6$ weeks old) & $\begin{array}{l}\text { Intraperitoneally injected } \mathrm{HT}(10 \mathrm{mg} / \mathrm{kg} \\
\text { or } 20 \mathrm{mg} / \mathrm{kg} \text {, daily, } 3 \text { weeks starting } 14 \mathrm{~d} \\
\text { after inoculation) }\end{array}$ & HT inhibits cholangiocarcinoma growth. & {$[73$} \\
\hline Human colon cancer (Caco-2) cells & HT ( $50 \mu \mathrm{M}$ for $24 \mathrm{~h}$ ) & $\begin{array}{l}\text { HT up-regulates CNR1 gene via epigenetic regulation (decrease in methylation at } \\
\text { CNR1 promoter), which is associated with reduced proliferation of Caco-2 cells. }\end{array}$ & {$[79$} \\
\hline Murine pre-adipocytes (3T3-L1) exposed to $\mathrm{H}_{2} \mathrm{O}_{2}$ & $\begin{array}{l}\text { Pretreatment with HT (1 and } 5 \mu \mathrm{M} \text { for } \\
24 \mathrm{~h} \text { ) }\end{array}$ & HT blunts the $\mathrm{H}_{2} \mathrm{O}_{2}$-induced GSH/GSSG alteration. & {$[84$} \\
\hline Human umbilical cord vein endothelial cells (HUVEC) & $\begin{array}{l}\text { HT, Tyr, and combination of both }(10 \mu \mathrm{M} \\
\text { for } 30 \mathrm{~min} \text { or } 18 \mathrm{~h})\end{array}$ & $\begin{array}{l}\text { The combination of HT with Tyr preserves cell functions from oxidative damage, } \\
\text { which correlates with rescuing their antioxidant properties. }\end{array}$ & {$[85$} \\
\hline $\begin{array}{l}\text { Human myelomonocytic cells (U937) and murine skeletal myoblasts (C2C12) } \\
\text { exposed to } \mathrm{H}_{2} \mathrm{O}_{2}\end{array}$ & $\begin{array}{l}\text { Pretreatment with Laur-HT }(5 \mu \mathrm{M}), \mathrm{HT} \\
(20 \mu \mathrm{M}) \text { or both combined }(20 \mu \mathrm{M}) \text { (for } \\
30 \mathrm{~min})\end{array}$ & $\begin{array}{l}\text { Laur-HyT has a protective antioxidant effect against } \mathrm{H}_{2} \mathrm{O}_{2} \text { treatment, greater than } \\
\text { HyT, so having a role in the prevention of apoptotic death in normal and tumor } \\
\text { cells. }\end{array}$ & {$[86$} \\
\hline $\begin{array}{l}\text { Human endothelial cells (ECV304) incubated with high glucose }(30 \mathrm{mM}) \text { in the } \\
\text { presence or absence of } 0-120 \mathrm{mM} \text { FFAs (oleic or linoleic acid) }\end{array}$ & $\begin{array}{l}\text { Co-treatment with HT }(10 \mu \mathrm{M} \text { for } 48 \mathrm{~h}) \\
\text { and polyphenol extract from EVOO }(10 \\
\mu \mathrm{M} \text { gallic acid equivalents for } 48 \mathrm{~h})\end{array}$ & $\begin{array}{l}\text { Treatments reduce the oxidative stress and modulate changes in NO and ET-1 } \\
\text { associated with experimental conditions that simulate diabetes (hyperglycemia } \\
\text { and a high level of FFA). }\end{array}$ & {$[87]$} \\
\hline $\begin{array}{l}\text { Human peripheral blood mononuclear cells (PBMC) and U937 monocytes activated } \\
\text { with PMA ( } 30 \mathrm{nM})\end{array}$ & $\begin{array}{l}\mathrm{HT}(1-10 \mu \mathrm{M} \text { for } 0-24 \mathrm{~h}) \text { prior to } \\
\text { activation with PMA }\end{array}$ & $\begin{array}{l}\text { HT blunts monocyte matrix invasive potential, reduces MMP-9 release and } \\
\text { expression, and inhibits PGE2 production and COX-2 expression, which are } \\
\text { mediated by inhibition of NF-KB transcription, PKC } \alpha \text { and } \beta 1 \text { activation. }\end{array}$ & {$[83$} \\
\hline Healthy subjects ( $22-37$ years) & $\begin{array}{l}\text { HT-enriched biscuits ( } 30 \mathrm{~g} \text { that contained } \\
5.25 \mathrm{mg} \text { of HT) or Non-enriched biscuits } \\
(30 \mathrm{~g}) \text { after overnight-fasting, only one } \\
\text { meal in a cross-overdesing }\end{array}$ & $\begin{array}{l}\text { Enriched biscuits consumption leads to a peak of posprandial levels of plasma } \\
\text { metabolites (mainly 3,4-dihydroxyphenylacetic acid (DOPAC)-sulphate, DOPAC, } \\
\text { HVA) between } 0.5 \text { and } 1 \mathrm{~h} \text {, which are also extensively excreted in urine and lower } \\
\text { postprandial ox-LDL levels. }\end{array}$ & {$[88$} \\
\hline Volunteers with mild hyperlipidemia & $\begin{array}{l}\text { HT purified ( } 99.5 \%) \text { from olive mill } \\
\text { waste }(5 \mathrm{mg} \text {, daily, for } 8 \text { weeks) }\end{array}$ & $\begin{array}{l}\text { HT does not influence markers of CVD, blood lipids, inflammatory markers, liver } \\
\text { or kidney functions and the electrolyte balance, but increased vitamin C levels. }\end{array}$ & {$[89]$} \\
\hline Human hepatocarcinoma (HepG2) cells under tunicamycin-induced ER stress & $\begin{array}{l}\text { HT or hepatic HT-derived metabolites } \\
\text { 3-O-HT glucuronide and } 4 \text {-O-HT } \\
\text { glucuronide }(10 \text { and } 25 \mu \mathrm{M} \text { for } 24 \mathrm{~h}) \\
\text { prior to tunicamycin treatment }\end{array}$ & $\begin{array}{l}\text { Both metabolites glucuronide inhibit ER stress, although they induce a milder } \\
\text { change in mRNA expression levels of both CHOP and BiP. }\end{array}$ & {$[90]$} \\
\hline
\end{tabular}


Giordano et al. [84] reported that long-term supplementation with nutritionally-relevant doses of HT-modulates adipose tissue and glutathione metabolism; that is, a 24-h pretreatment with HT, followed by exposition to $\mathrm{H}_{2} \mathrm{O}_{2}$, maintained a higher intracellular total and oxidized glutathione (GSSG)-to-reduced glutathione (GSH) ratio compared with $\mathrm{H}_{2} \mathrm{O}_{2}$ alone, indicating a preventive activity against oxidative stress [84].

HT anti-inflammatory and antioxidant properties could also be very interesting for cardiovascular health, as evidenced by a recent randomized control trial, where HT, used as a functional ingredient in biscuits, has shown to lower postprandial oxidized low-density lipoprotein levels [88]. However, other studies suggested that the main HT effects are a consequence of increasing endogenous vitamin $C$ levels, since it did not influence blood lipids, inflammatory markers, liver or kidney functions [89]. In particular, HT has been shown to beneficially impact the hemostatic profile, exerting antiplatelet and antithrombotic properties [25,91].

Concerning HT derivatives, Burattini et al. [86] investigated the effects of HT and the corresponding ester hydroxytyrosyl laurate (laur-HT) in U937 cells (a human monocytoid cell line) and in $\mathrm{C} 2 \mathrm{C} 12$ myoblasts (a murine proliferating muscle cell model) after apoptotic death induction. The results obtained showed that laur-HyT had a protective antioxidant effect against $\mathrm{H}_{2} \mathrm{O}_{2}$ treatment. In an interesting view, Giordano et al. [90] synthesized two among the most physiologically prominent HT hepatic metabolites, i.e., 3-O-HT glucuronide and 4-O-HT glucuronide and tested their activities on endoplasmic reticulum (ER) stress in human hepatocarcinoma HepG2 cells. Both compounds inhibited tunicamycin-induced ER stress that can lead to unfolded protein response and ER-initiated apoptosis that have been implicated in the pathophysiology of various CVDs, including heart failure and ischemic heart [92]. An assay performed by Storniolo et al. [87] evidenced that HT and some polyphenols contained in VOO or EVOO could prevent negative consequences of less "healthy" diets rich in fat and/or sugars. It was demonstrated that treatments with HT or polyphenol extract from EVOO reverted multiple changes induced by high glucose and free fatty acids (FFAs) (features found in diabetes patients) which included nitric oxide (NO) level reduction and increased endothelin-1 (ET-1) levels induced by acetylcholine by modulating intracellular $\mathrm{Ca}^{2+}$ levels and endothelial nitric oxide synthase phosphorylation. This has important implications since endothelium participates in blood pressure regulation through the release of potent vasodilator and vasoconstrictor agents, such as NO and ET-1, respectively. These last findings might have implications for reducing risks of many CVDs, where the dysfunction of the endothelium is the underlying causative factor.

\subsection{Tyrosol}

Tyr is a simple phenol, namely a phenyl ethyl alcohol. As it occurs with HT, it might be released during storage of VOO by hydrolytic mechanisms from complex phenols as secoiridoids $[68,69]$. Tyr shows potent influences on cell proliferation, cell cycle progression, apoptosis and arachidonic acid metabolism in cancer cells $[18,93,94]$. Prevention of the persistent damaging effects of ROS has also been reported for HT with Tyr, either per se or in combination (each at $10 \mu \mathrm{M}$ ) (at the recommended concentration from EVOO consumption) in human umbilical cord vein endothelial (HUVEC) cells [85].

\section{3. (-)-Oleocanthal}

Oleocanthal is the term used to refer to p-HPEA-EDA $[95,96]$ that presents two possible enantiomers. Importantly, both forms cause a dose-dependent inhibition of cyclo-oxygenase (COX)-1 and COX-2 activities comparable to that of ibuprofen but have no effect on lipoxygenasein vitro. Moreover, oleocanthal presents potent pharmacological actions in attenuating inflammatory mediators, such as iNOS [97,98]. Interestingly, oleocanthal has shown to resist hydrolysis under stomach-simulated conditions and cooperates inhibiting growth of Helicobacter pylori that has been associated with digestive system pathologies, such as gastric cancer and petic ulcer [99]. In addition to its putative anti-inflammatory potential, (-)-oleocanthal has shown anti-proliferative, but also anti-migratory activity against different cancer cell lines (Table 2). It also promotes cell apoptosis and induces DNA fragmentation in HT-29 cells, which would depend on 
activation of both, caspase- 3 and poly-adenosine diphosphate-ribose polymerase, and phosphorylation of p53 [98]. In in vivostudies, oleocanthal inhibits proliferation and transformation of JB6 Cl41 epidermal cells from mouse, by suppressing activation of extracellular signal-regulated kinases $1 / 2$ and p90 ribosomal S6 kinase [98]. Akl et al. [100] showed that (-)-oleocanthal treatment causes a dose-dependent inhibition of Hepatocyte Growth Factor (HGF)-induced cell migration and invasion on different human breast cancer cell lines (MDA-MB-231, MCF-7 and BT-474), along with the arrest of cell cycle at G1/S phase and cell proliferation. These effects are found to be mediated, at least in part, via the inhibition of HGF-induced c-Met activation and its downstream mitogenic signaling pathways (RAS, PI3K, beta-catenin, or STAT pathways) that are related to proliferation and surveillance of cells. In the model used, this effect would be associated with the blockade of epithelial-to-mesenchymal transition and a reduction in cellular motility. In relation with previous findings, Pei et al. [101] showed that (-)-oleocanthal inhibits human hepatocellular carcinoma tumor growth and metastasis through STAT3 inactivation. On the other hand, (-)-oleocanthal cell death induces both primary necrotic and apoptotic cell death via induction of lysosomal membrane permeabilization on human pancreatic (BxPC3), prostate (PC3) and breast (MDA-MB-231) cancer cell lines [102]. Khanfar et al. [103] also reported that docked oleocanthal inhibita the growth of several breast cancer cell lines (MCF-7 and T47D) at low micromolar concentrations in a dose-dependent manner. (-)-oleocanthal treatment also causes a marked down-regulation of phosphorylated mTOR in metastatic breast cancer cell lines (MDA-MB-231) [103], which suggests an important stimulation of autophagy initiation by this compound with negative consequences for cancer cells viability. Finally, Ayoub et al. [104] showed that (-)-oleocanthal inhibites growth of BT-474, MCF-7 and T-47D human breast cancer cells in mitogen-free media and in $17 \beta$-estradiol-supplemented media. Thus, (-)-oleocanthal can reduce total levels of estrogen receptors in BT-474 cells both in vitro and in vivo and show a potential beneficial effect in suppressing the growth of hormone-dependent breast cancer. Several treatments with intraperitoneal injections support its anti-cancer activity on tumor cell growth in different cancer models, such as the orthotopic model of breast cancer in athymic nude mice [100] and human hepatocellular carcinoma tumor growth [101]. Similarly, inhibitory activities on proliferation [104] and metastasis by inactivating STAT3 [101] have also been reported.

Along with the anticancer effects, some protective effects against deleterious effects of chemotherapeutic drugs on health cell models have also been reported. Ayoub et al. [104] explored the effect of (-)-oleocanthal treatment on growth of luminal breast cancer cells (BT-474, MCF-7 and T-47D) combined with tamoxifen. Results showed that (-)-oleocanthal inhibits growth of BT-474, MCF-7 and T-47D human breast cancer cells in mitogen-free media. Combined (-)-oleocanthal and tamoxifen treatments result in a synergistic growth inhibition of all cells. As was suggested for HT, these changes could also be present when this compound is orally administrated, although further studies are needed to prove this hypothesis.

\subsection{Oleuropein and Oleuropein Aglycone}

Oleuropein (OLE) is an ester of hydroxytyrosol (3,4-DHPEA) and the elenolic acid glucoside [46]. OLE belongs to a specific group of coumarin-like compounds, the secoiridoids that are glycosidically bound and produced from the secondary metabolism of terpenes. This compound has shown in vivo to exert preventive effects against early steps of cancer onset. In an azoxymethane (AOM)-induced mouse model of colerectal cancer, OLE has shown to reduce tumor incidence from 57 to $14 \%$ in the medial colon segment, which is related to the prevention of DNA damage (i.e., mutations) by the carcinogen [105] (Table 3). Concerning anti-cancer activity, previous studies have shown that OLE inhibits cell proliferation and induces apoptosis in breast, colorectal and thyroid cancer [106-108]. More recently, Yan et al. [109] have investigated the OLE effects on hepatocellular carcinoma cells, finding a reduction of HepG2 cell viability, as well as apoptosis induction in a dose-dependent manner through activation of the caspase pathway. This effect was correlated with ROS generation that could be responsible of both effects. Additionally, changes in proapoptotic Bcl-2 family members (BAX and Bcl-2) and inhibition of PI3K/Akt signaling pathway were reported to be involved in OLE-induced apoptosis, which could be ROS-dependent, at least in part. 
Table 2. Studies on (-)-oleocanthal effects on cancer and CVDs in the last five years.

\begin{tabular}{|c|c|c|c|}
\hline Sample & Treatments & Main Results & Ref. \\
\hline Human breast cancer cells (MDA-MB-231, MCF-7 and BT-474) & $\begin{array}{l}\text { (-)-Oleocanthal (10-100 } \mathrm{ng} / \mathrm{mL} \text { for } 24, \\
48 \text { and } 72 \mathrm{~h})\end{array}$ & $\begin{array}{l}\text { (-)-Oleocanthal inhibits growth and causes a dose-dependent inhibition of } \\
\text { HGF-induced cell migration, invasion and G1/S cell cycle progression. }\end{array}$ & [100] \\
\hline $\begin{array}{l}\text { Human pancreatic (BxPC3), prostate (PC3) and breast (MDA-MB-231) } \\
\text { cancer cells }\end{array}$ & $\begin{array}{l}\text { (-)-Oleocanthal }(0.2-20 \mu \mathrm{M} \text { for } 4,24,48 \\
\text { and } 72 \mathrm{~h})\end{array}$ & $\begin{array}{l}\text { (-)-Oleocanthal induces cell death, primary necrotic and apoptotic cell death } \\
\text { via induction of lysosomal membrane permeabilization. }\end{array}$ & [102] \\
\hline $\begin{array}{l}\text { Human breast cancer (MCF-7, T47D) metastatic breast cancer } \\
\text { (MDA-MB-2318), CRC (Caco-2) and adenocarcinoma (HeLa) cells }\end{array}$ & $\begin{array}{l}\text { (-)-Oleocanthal }(10 \mu \mathrm{M} \text { for } 72 \mathrm{~h} \text { on } \\
\text { MDA-MB-231) }\end{array}$ & $\begin{array}{l}\text { (-)-Oleocanthal shows anti-proliferative against several breast cancer cell } \\
\text { lines and down-regulates the levels of p-mTOR in the metastatic breast cancer } \\
\text { cell line (MDA-MB-231). }\end{array}$ & [103] \\
\hline Human hepatocellular cell lines (Huh-7, HepG2 and HCCLM3) & $\begin{array}{l}\text { (-)-Oleocanthal }(0-80 \mu \mathrm{M} \text { for } 12,24,48 \\
\text { and } 72 \mathrm{~h})\end{array}$ & $\begin{array}{l}\text { (-)-Oleocanthal inhibits human hepatocellular carcinoma by inactivating } \\
\text { STAT3. }\end{array}$ & [101] \\
\hline Human breast cancer cells (BT-474, MCF-7 and T-47D) & $\begin{array}{l}\text { (-)-Oleocanthal }(5-60 \mu \mathrm{M} \text { for } 48 \mathrm{~h} \text { in } \\
\text { BT-474 and MCF-7 cells; } 10-100 \mu \mathrm{M} \text { for } \\
24 \text { and } 48 \mathrm{~h} \text { in T-47D cells) }\end{array}$ & $\begin{array}{l}\text { (-)-Oleocanthal suppresses growth of all cancer cells, in part, by reducing } \\
\text { total levels of ER } \alpha \text {. }\end{array}$ & [104] \\
\hline $\begin{array}{l}\text { Female athymic nude Foxn } 1^{\text {nu }} / \text { Foxn } 1^{+} \text {mice ( } 4-5 \text { weeks old) in human tumor } \\
\text { xenograft model }\end{array}$ & $\begin{array}{l}\text { Intraperitoneally injected } \\
\text { (-)-oleocanthal ( } 5 \mathrm{mg} / \mathrm{kg}, 3 \mathrm{~d} / \text { week, } 33 \\
\mathrm{~d} \text { starting } 5 \mathrm{~d} \text { after inoculation) }\end{array}$ & (-)-Oleocanthal suppresses tumor growth. & {$[100]$} \\
\hline $\begin{array}{l}\text { BALB / c athymic nude mice a in vivo human lung metastasis model } \\
\text { hepatocellular ( } 4-6 \text { weeks old, male) }\end{array}$ & $\begin{array}{l}\text { Intraperitoneally injected } \\
(-) \text {-oleocanthal }(5 \mathrm{mg} / \mathrm{kg} \text { or } 10 \mathrm{mg} / \mathrm{kg} \text {, } \\
\text { daily, } 5 \text { weeks) }\end{array}$ & $\begin{array}{l}\text { (-)-Oleocanthal suppresses hepatocellular tumor growth and impedes } \\
\text { carcinoma metastasis in lung by inactivating STAT3. }\end{array}$ & [101] \\
\hline $\begin{array}{l}\text { Female thymic nudeFoxn } 1^{\text {nu }} / \text { Foxn } 1^{+} \text {mice ( } 4-5 \text { weeks old) inoculated with } \\
\text { BT-474 cells }\end{array}$ & $\begin{array}{l}\text { Intraperitoneally injected } \\
(-) \text {-oleocanthal }(5 \mathrm{mg} / \mathrm{kg} \text { per } \mathrm{d} \text { or } 10 \\
\mathrm{mg} / \mathrm{kg}, 3 \mathrm{~d} / \text { week, } 43 \mathrm{~d})\end{array}$ & (-)-Oleocanthal reduces total levels of estrogen receptors in BT-474 cells. & [104] \\
\hline
\end{tabular}


Table 3. Studies on OLE (Oleuropein) and OLE aglycone effects on cancer and CVDs in the last five years.

\begin{tabular}{|c|c|c|c|}
\hline Sample & Treatments & Main Results & Ref. \\
\hline $\begin{array}{l}\text { Human umbilical vein endothelial cells (HUVECs) and dermal microvascular } \\
\text { endothelial cells (HMVECs-d-Ad) }\end{array}$ & OLE $(0-50 \mu \mathrm{M}$ for 18 and $24 \mathrm{~h})$ & OLE does not inhibit VEGFR-2 signaling pathway. & [77] \\
\hline $\begin{array}{l}\text { Mice with colon cancer induced by AOM injections }(10 \mathrm{mg} / \mathrm{kg}, 1 \mathrm{~d} / \text { week for } \\
6 \text { weeks) }\end{array}$ & $\begin{array}{l}\text { Basal diet either enriched or not with } \\
\text { OLE (125 mg/kg), ( } 7 \text { or } 17 \text { weeks) }\end{array}$ & $\begin{array}{l}\text { OLE-enriched diet prevents the preneoplastic lesions in different colon } \\
\text { segments, reducing the severity of crypt dysplasia and DNA damage in } \\
\text { peripheral leukocytes. }\end{array}$ & [105] \\
\hline Mouse atrial myocytes (HL-1) & OLE-aglycone ( $60 \mu \mathrm{M}$ for $24 \mathrm{~h})$ & $\begin{array}{l}\text { Data suggest a possible use of OLE-aglycone to treat human transthyretin } \\
\text { (TTR)-related pathologies with the aim to relieve or to delay the occurrence of } \\
\text { the most severe cardiac symptoms. }\end{array}$ & [110] \\
\hline Luminal MCF-7 breast cancer cell & OLE $(100 \mu \mathrm{M}$ or $200 \mu \mathrm{M}$ for $72 \mathrm{~h})$ & $\begin{array}{l}\text { OLE-induced apoptosis, which is associated with Bax gene expression } \\
\text { up-regulation and Bcl2 gene expression down-regulation via p53 pathway } \\
\text { activation. }\end{array}$ & [106] \\
\hline Thyroid tumorTPC- 1 and BCPAP cells & $\begin{array}{l}\text { OLE and Ac-OLE }(10,50 \text {, and } 100 \mathrm{mM} \\
\text { for } 48 \mathrm{~h})\end{array}$ & $\begin{array}{l}\text { Both treatments inhibit cell proliferation, and decrease } \mathrm{H}_{2} \mathrm{O}_{2} \text {-induced } \mathrm{ROS} \\
\text { levels, and p-Akt and p-ERK levels. Thus, it exerts antioxidant and inhibitory } \\
\text { effects on growth-promoting signal pathways. }\end{array}$ & [107] \\
\hline Human colon adenocarcinoma (HT-29) cells & OLE $(0 \mu \mathrm{M}-800 \mu \mathrm{M}$ for 24,48 and $72 \mathrm{~h})$ & $\begin{array}{l}\text { OLE inhibits cell growth and induces apoptosis, which is associated with a } \\
\text { decrease in HIF- } 1 \alpha \text { protein and an increase p53, but not to changes in IkB- } \alpha \\
\text { and MAPK cascade proteins. }\end{array}$ & [108] \\
\hline Hepatocellular carcinoma (Huh7) and human hepatoma (HepG2) cells & $\operatorname{OLE}(0,20,40,60,80$ or $100 \mu \mathrm{M}$ for $24 \mathrm{~h})$ & $\begin{array}{l}\text { OLE induces apoptosis in HepG2 cells in a dose-dependent manner, via } \\
\text { caspase activation which is mediated by changes in proapoptotic Bcl-2 family } \\
\text { members, (BAX and Bcl-2) levels, down-regulation of PI3K/AKT signaling } \\
\text { pathway, and ROS production increases. }\end{array}$ & [109] \\
\hline
\end{tabular}


On the other hand, OLE aglycone presents a similar structurebut with EA it is in the agliconed form, instead of the glycosydized form.Secoiridoids of VOO in aglyconic forms arise from glycosides in olive fruits by hydrolysis of endogenous $\beta$-glucosidases during crushing and malaxation [111]. First studies supporting the potential use of OLE aglycone as a nutraceutical in relation to cardiovascular health was provided, owing to the anti-inflammatory activities observed in a carrageenan-challenged mouse model of inflammation [112]. In addition, OLE aglycone inhibits TNF $\alpha$-induced MMP-9 in a monocyte cell line, which could also been observed against other events induced by pro-inflammatory stimuli [113]. In more recent years (Table 4), OLE-aglycone has shown to be able to interfere with transthyretin (TTR) aggregation and to protect mouse HL-1 cardiomyocyte cells against the cytotoxicity induced by previously grown amyloid aggregates of wild-type TTR and L55P-TTR [110]. The results indicated that OLE-aglycone reduces amyloid TTR toxicity, specifically to a cardiac cell line.

Table 4. Studies on other minor compound effects on cancer and CVDs in the last five years.

\begin{tabular}{|c|c|c|c|}
\hline Sample & Treatments & Main Results & Ref. \\
\hline $\begin{array}{l}\text { Human umbilical vein endothelial } \\
\text { cells (HUVECs) and dermal } \\
\text { microvascular endothelial cells } \\
\text { (HMVECs-d-Ad) }\end{array}$ & $\begin{array}{l}\text { Taxifolin }(0-50 \mu \mathrm{M} \text { for } 18 \\
\text { and } 24 \mathrm{~h})\end{array}$ & $\begin{array}{l}\text { Taxifolin inhibits VEGFR-2 } \\
\text { signaling pathway. }\end{array}$ & [77] \\
\hline $\begin{array}{l}\text { Human breast cancer cells } \\
\text { (MDA-MB-231 and MCF7) }\end{array}$ & $\begin{array}{l}\mathrm{AO} \text { and } \mathrm{MA}(0.001-100 \mu \mathrm{M} \\
\text { for } 4,24,48 \text { and } 72 \mathrm{~h})\end{array}$ & $\begin{array}{l}\text { AO inhibits the proliferation } \\
\text { and increases the oxidative } \\
\text { stress of highly invasive cells. }\end{array}$ & [114] \\
\hline $\begin{array}{l}\text { Invasive human breast cancer cells } \\
\text { (MDA-MB-231) }\end{array}$ & $\begin{array}{l}\text { UV and ER }(0.001-100 \mu \mathrm{M} \\
\text { for } 4,24,48 \text { and } 72 \mathrm{~h})\end{array}$ & $\begin{array}{l}\text { UV protects DNA from damage, } \\
\text { whereas ER enhances damage } \\
\text { to DNA. }\end{array}$ & [115] \\
\hline $\begin{array}{l}\text { SUM-159 cells subcutaneously } \\
\text { injected into athymic nude mice; } \\
\text { or into the } 2 \text { nd right mammary fat } \\
\text { pad of female SCID/Beige mice }\end{array}$ & $\begin{array}{l}\text { Pretreatment with DOA (10, } \\
20 \mu \mathrm{mol} / \mathrm{L} \text { for } 3 \mathrm{~d} \text { ); or } \\
\text { graded concentrations of } \\
\text { DOA (for } 2 \mathrm{~h} \text { ) }\end{array}$ & $\begin{array}{l}\text { DOA blocks the formation of } \\
\text { multicellular tumorspheres } \\
\text { generated from single-founder } \\
\text { stem-like cells in a panel of } \\
\text { genetically diverse breast cancer } \\
\text { models and suppresses CSC-like } \\
\text { states responsible for } \\
\text { maintaining tumor initiating cell } \\
\text { properties within breast } \\
\text { cancer populations. }\end{array}$ & [116] \\
\hline
\end{tabular}

\subsection{Others Minor Compounds}

In the last few years, other additional compounds found in VOO or EVOO, but in less amount, have been tested to determine their potential for health maintenance. Thus far, oleanolic acid and maslinic acid are known to have beneficial properties against different types of cancers [114,117-124]. Recently, Sánchez-Quesada et al. [114] sought to elucidate whether both compounds possessed chemopreventive activity on two cell lines of human breast cancer cells (MDA-MB-231 and MCF7) (Table 4). The results showed that oleanolic acid inhibits the proliferation and causes oxidative stress of highly invasive cells. Other two triterpenic dialcohols, uvaol and erythrodiol, have been reported to present anti-tumoral effects in leukemic cells, in skin mice tumors and in astrocytoma cells $[117,125-127]$, but there is no evidence about their effects in highly invasive human breast cancer cells. For this purpose, Sánchez-Quesada et al. [115] have evaluated their effects on cell proliferation, viability, cell cycle profile, apoptotic induction, oxidative stress and DNA oxidative damage in MDA-MB-231. Results showed that uvaol protects DNA from damage, whereas erythrodiol enhances damage to DNA. On the other hand, Lamy et al. [77] also reported that taxifolin is a strong inhibitor of in vitroangiogenesis by the inhibitory effect on specific autophosphorylation sites of VEGFR-2. Finally, Corominas-Faja et al. [116] showed that the secoiridoid decarboxymethyl OLE aglycone (DOA) blocks the multicellular tumorspheres formation from single-founder stem-like breast cancer cells. Moreover, mice orthotopically injected with CSC-enriched breast cancer-cell 
populations remain more time without cancer if the cells are pretreated with DOA, supporting the capability of this compound to reduce tumor-forming capacity. In addition, it has been evidenced that these effects could be due, at least in part, to a dual activity as an mTOR/DNA methyltransferase inhibitor, which can suppress CSC-like states responsible for maintaining tumor-initiating cells [116]. The election of this interesting compound is based on an phenotypic drug discovery in silico approach coupled to mechanism-of-action profiling and target deconvolution, identifying DOA, among the different phenolic components of EVOO, as an interesting compound capable to selectively target subpopulations of CSC with typical functional traits in breast cancer.

\section{Conclusions}

The present work aimed to explore the effects of the main phenolic compounds isolated from OO on different cancer or CVD aspects in studies published during the last five years. During this period, the potential preventive or therapeutic properties of phenolic compounds have been studied with special emphasis in cancer.

HT reduced cellular viability by means of different mechanisms including oxidative stress promotion and the PI3K/Akt pathway stimulation. Moreover, it induced apoptosis and arrest of a cellular cycle, leading to a cell proliferation reduction. An inhibitory action on specific autophosphorylation sites of VEGFR-2 was also reported, leading to the inhibition of endothelial cell signaling with a reduction of angiogenesis.

With respect to oleocanthal, it reduced cellular viability by lysosomal membrane permeabilization and/or overstimulation of autophagy initiation, processes that would lead to cell death. As for HT, it promoted the arrest of cell cycle, reducing therefore the cellular proliferation. In some cell lines, this effect was also due to their action in the estrogen receptors. Moreover, it suppressed HFG-induced activation of STAT3, which prevent malignant cell migration and invasiveness.

Finally, OLE showed a reduction of the DNA oxidation as a consequence of the treatment with some carcinogens. This would delay or prevent the carcinogenesis process initiation.

Overall, these results would indicate that HT and oleocanthal presented promising effects in vitro and in vivo studies, suggesting their potential as nutraceuticals for the prevention and management of NCDs.

Author Contributions: M.B. and J.L.Q. conceived the idea. P.R.-R. and A.V.-L. prepared the first draft of the review with the input of T.Y.F.-H., M.G. and S.A.; D.C., J.Z. and P.P.M. prepared the tables and figures. F.G. and S.B. edited the paper.

Acknowledgments: Patricia Reboredo-Rodríguez acknowledges Xunta de Galicia for her post-doctoral contract. Alfonso Varela-López is supported by a fellowship from Alfonso Martin Escudero Foundation.

Conflicts of Interest: The authors declare no conflicts of interest.

$\begin{array}{ll}\text { Abbreviations } & \\ \text { AO } & \text { oleanolic acid } \\ \text { AOM } & \text { azoxymethane } \\ \text { COX-1 } & \text { cyclooxygenase-1 } \\ \text { COX-2 } & \text { cyclooxygenase-2 } \\ \text { CSC } & \text { cancer stem cell } \\ \text { CVDs } & \text { cardiovascular diseases } \\ \text { DOA } & \text { decarboxymethyl OLE aglycone } \\ \text { EA } & \text { elenolic acid } \\ \text { ECS } & \text { endocannabinoid system } \\ \text { ER } & \text { endoplasmic reticulum } \\ \text { ERK } & \text { extracellular signal-regulated kinase } \\ \text { ET-1 } & \text { endothelin-1 } \\ \text { EVOO } & \text { extra virgin olive oil }\end{array}$




\begin{tabular}{|c|c|}
\hline FFA & free fatty acid \\
\hline GSH & glutathione \\
\hline GSSG & oxidized glutathione \\
\hline HGF & hepatocyte growth factor \\
\hline HT & hydroxytyrosol \\
\hline HUVEC & human umbilical cord vein endothelial \\
\hline IL-1 $\beta$ & interleukin 1 beta \\
\hline IL-10 & interleukin-10 \\
\hline iNOS & inducible nitric oxide synthase \\
\hline Laur-HT & hydroxytyrosyl laurate \\
\hline LPS & lipopolysaccharide \\
\hline MD & Mediterrean Diet \\
\hline MMP & matrix metalloproteinase \\
\hline MMP-9 & matrix metalloproteinase 9 \\
\hline MMP-9/NGAL & neutrophil gelatinase-associated lipocalin complex \\
\hline NF- $k B$ & nuclear factor-kappa B \\
\hline NO & nitric oxide \\
\hline OLE & oleuropein \\
\hline p-mTOR & phosphorylated mammalian target of rapamycin \\
\hline PI3K & phosphoinositide 3-kinase \\
\hline ROS & reactive oxygen species \\
\hline $\mathrm{TNF} \alpha$ & tumor necrosis factor $\alpha$ \\
\hline TTR & transthyretin \\
\hline Tyr & tyrosol \\
\hline UV & uvaol \\
\hline VEGF & vascular endothelial growth factor \\
\hline VEGFR-2 & vascular endothelial growth factor receptor- 2 \\
\hline $\mathrm{VOO}$ & virgin olive oil \\
\hline
\end{tabular}

\section{References}

1. GBD 2015 Risk Factors Collaborators. Global, regional, and national comparative risk assessment of 79 behavioural, environmental and occupational, and metabolic risks or clusters of risks, 1990-2015: A systematic analysis for the Global Burden of Disease Study 2015. Lancet 2016, 388, 1659-1724. [CrossRef]

2. Bernard, W.S.; Wilde, C.P. World Cancer Report 2015; WHO: Geneva, Switzerland, 2015.

3. Anand, P.; Kunnumakara, A.B.; Sundaram, C.; Harikumar, K.B.; Tharakan, S.T.; Lai, O.S.; Sung, B.; Aggarwal, B.B. Cancer is a preventable disease that requires major lifestyle changes. Pharm. Res. 2008, 25, 2097-2116. [CrossRef] [PubMed]

4. Lanier, J.B.; Bury, D.C.; Richardson, S.W. Diet and physical activity for cardiovascular disease prevention. Am. Fam. Phys. 2016, 93, 919-924.

5. Willett, W.C.; Koplan, J.P.; Nugent, R.; Dusenbury, C.; Puska, P.; Gaziano, T.A. Prevention of chronic disease by means of diet and lifestyle changes. In Disease Control Priorities in Developing Countries; Jamison, D.T., Breman, J.G., Measham, A.R., Alleyne, G., Claeson, M., Evans, D.B., Jha, P., Mills, A., Musgrove, P., Eds.; World Bank: Washington, DC, USA, 2006; ISBN 978-0-8213-6179-5.

6. World Health Organization. Diet, Nutrition, and the Prevention of Chronic Diseases: Report of a WHO-FAO Expert Consultation; World Health Organization: Geneva, Switzerland, 2003; ISBN 978-92-4-120916-8.

7. FAO. Fats and Fatty Acids in Human Nutrition: Report of an Expert Consultation: 10-14 November 2008, Geneva; Food and Agriculture Organization of the United Nations, Ed.; FAO Food and Nutrition Paper; Food and Agriculture Organization of the United Nations: Rome, Italy, 2010; ISBN 978-92-5-106733-8.

8. Hooper, L.; Abdelhamid, A.; Moore, H.J.; Douthwaite, W.; Skeaff, C.M.; Summerbell, C.D. Effect of reducing total fat intake on body weight: Systematic review and meta-analysis of randomised controlled trials and cohort studies. BMJ 2012, 345, e7666. [CrossRef] [PubMed] 
9. De Lorgeril, M.; Salen, P.; Martin, J.L.; Monjaud, I.; Delaye, J.; Mamelle, N. Mediterranean diet, traditional risk factors, and the rate of cardiovascular complications after myocardial infarction: Final report of the Lyon Diet Heart Study. Circulation 1999, 99, 779-785. [CrossRef] [PubMed]

10. Singh, R.B.; Dubnov, G.; Niaz, M.A.; Ghosh, S.; Singh, R.; Rastogi, S.S.; Manor, O.; Pella, D.; Berry, E.M. Effect of an Indo-Mediterranean diet on progression of coronary artery disease in high risk patients (Indo-Mediterranean Diet Heart Study): A randomised single-blind trial. Lancet 2002, 360, 1455-1461. [CrossRef]

11. Stark, A.H.; Madar, Z. Olive oil as a functional food: Epidemiology and nutritional approaches. Nutr. Rev. 2002, 60, 170-176. [CrossRef] [PubMed]

12. Trichopoulou, A.; Bamia, C.; Lagiou, P.; Trichopoulos, D. Conformity to traditional Mediterranean diet and breast cancer risk in the Greek EPIC (European Prospective Investigation into Cancer and Nutrition) cohort. Am. J. Clin. Nutr. 2010, 92, 620-625. [CrossRef] [PubMed]

13. Visioli, F.; Galli, C. The effect of minor constituents of olive oil on cardiovascular disease: New findings. Nutr. Rev. 1998, 56, 142-147. [CrossRef] [PubMed]

14. Fortes, C.; Forastiere, F.; Farchi, S.; Mallone, S.; Trequattrinni, T.; Anatra, F.; Schmid, G.; Perucci, C.A. The protective effect of the Mediterranean diet on lung cancer. Nutr. Cancer 2003, 46, 30-37. [CrossRef] [PubMed]

15. Schwingshackl, L.; Hoffmann, G. Adherence to Mediterranean diet and risk of cancer: An updated systematic review and meta-analysis of observational studies. Cancer Med. 2015, 4, 1933-1947. [CrossRef] [PubMed]

16. Grosso, G.; Marventano, S.; Yang, J.; Micek, A.; Pajak, A.; Scalfi, L.; Galvano, F.; Kales, S.N. A comprehensive meta-analysis on evidence of Mediterranean diet and cardiovascular disease: Are individual components equal? Crit. Rev. Food Sci. Nutr. 2017, 57, 3218-3232. [CrossRef] [PubMed]

17. Robles-Almazan, M.; Pulido-Moran, M.; Moreno-Fernandez, J.; Ramirez-Tortosa, C.; Rodriguez-Garcia, C.; Quiles, J.L.; Ramirez-Tortosa, M. Hydroxytyrosol: Bioavailability, toxicity, and clinical applications. Food Res. Int. 2018, 105, 654-667. [CrossRef] [PubMed]

18. Corona, G.; Spencer, J.; Dessì, M. Extra virgin olive oil phenolics: Absorption, metabolism, and biological activities in the GI tract. Toxicol. Ind. Health 2009, 25, 285-293. [CrossRef] [PubMed]

19. Bach-Faig, A.; Berry, E.M.; Lairon, D.; Reguant, J.; Trichopoulou, A.; Dernini, S.; Medina, F.X.; Battino, M.; Belahsen, R.; Miranda, G.; et al. Mediterranean Diet Foundation Expert Group Mediterranean diet pyramid today. Science and cultural updates. Public Health Nutr. 2011, 14, 2274-2284. [CrossRef] [PubMed]

20. Pelucchi, C.; Bosetti, C.; Negri, E.; Lipworth, L.; La Vecchia, C. Olive oil and cancer risk: An update of epidemiological findings through 2010. Curr. Pharm. Des. 2011, 17, 805-812. [CrossRef] [PubMed]

21. Buckland, G.; Gonzalez, C.A. The role of olive oil in disease prevention: A focus on the recent epidemiological evidence from cohort studies and dietary intervention trials. Br. J. Nutr. 2015, 113 (Suppl. 2), S94-S101. [CrossRef]

22. Braga, C.; Vecchia, C.L.; Franceschi, S.; Negri, E.; Parpinel, M.; Decarli, A.; Giacosa, A.; Trichopoulos, D. Olive oil, other seasoning fats, and the risk of colorectal carcinoma. Cancer 1998, 82, 448-453. [CrossRef]

23. Psaltopoulou, T.; Kosti, R.I.; Haidopoulos, D.; Dimopoulos, M.; Panagiotakos, D.B. Olive oil intake is inversely related to cancer prevalence: A systematic review and a meta-analysis of 13,800 patients and 23,340 controls in 19 observational studies. Lipids Health Dis. 2011, 10, 127. [CrossRef] [PubMed]

24. Xin, Y.; Li, X.Y.; Sun, S.R.; Wang, L.X.; Huang, T. Vegetable oil intake and breast cancer risk: A meta-analysis. Asian Pac. J. Cancer Prev. 2015, 16, 5125-5135. [CrossRef] [PubMed]

25. López-Miranda, J.; Pérez-Jiménez, F.; Ros, E.; De Caterina, R.; Badimón, L.; Covas, M.I.; Escrich, E.; Ordovás, J.M.; Soriguer, F.; Abiá, R.; et al. Olive oil and health: Summary of the II international conference on olive oil and health consensus report, Jaén and Córdoba (Spain) 2008. Nutr. Metab. Cardiovasc. Dis. 2010, 20, 284-294. [CrossRef] [PubMed]

26. Buckland, G.; Mayén, A.L.; Agudo, A.; Travier, N.; Navarro, C.; Huerta, J.M.; Chirlaque, M.D.; Barricarte, A.; Ardanaz, E.; Moreno-Iribas, C.; et al. Olive oil intake and mortality within the Spanish population (EPIC-Spain). Am. J. Clin. Nutr. 2012, 96, 142-149. [CrossRef] [PubMed]

27. Buckland, G.; Travier, N.; Barricarte, A.; Ardanaz, E.; Moreno-Iribas, C.; Sánchez, M.-J.; Molina-Montes, E.; Chirlaque, M.D.; Huerta, J.M.; Navarro, C.; et al. Olive oil intake and CHD in the European Prospective Investigation into Cancer and Nutrition Spanish cohort. Br. J. Nutr. 2012, 108, 2075-2082. [CrossRef] [PubMed] 
28. Bendinelli, B.; Masala, G.; Saieva, C.; Salvini, S.; Calonico, C.; Sacerdote, C.; Agnoli, C.; Grioni, S.; Frasca, G.; Mattiello, A.; et al. Fruit, vegetables, and olive oil and risk of coronary heart disease in Italian women: The EPICOR Study. Am. J. Clin. Nutr. 2011, 93, 275-283. [CrossRef] [PubMed]

29. Martínez-González, M.A.; Dominguez, L.J.; Delgado-Rodríguez, M. Olive oil consumption and risk of CHD and/or stroke: A meta-analysis of case-control, cohort and intervention studies. Br. J. Nutr. 2014, 112, 248-259. [CrossRef] [PubMed]

30. Cicero, A.F.G.; Nascetti, S.; López-Sabater, M.C.; Elosua, R.; Salonen, J.T.; Nyyssönen, K.; Poulsen, H.E.; Zunft, H.-J.F.; Kiesewetter, H.; de la Torre, K.; et al. EUROLIVE Study Group Changes in LDL fatty acid composition as a response to olive oil treatment are inversely related to lipid oxidative damage: The EUROLIVE study. J. Am. Coll. Nutr. 2008, 27, 314-320. [CrossRef] [PubMed]

31. Covas, M.-I.; Konstantinidou, V.; Fitó, M. Olive Oil and Cardiovascular Health. J. Cardiovasc. Pharmacol. 2009, 54, 477-482. [CrossRef] [PubMed]

32. De la Torre-Carbot, K.; Chávez-Servín, J.L.; Jaúregui, O.; Castellote, A.I.; Lamuela-Raventós, R.M.; Nurmi, T.; Poulsen, H.E.; Gaddi, A.V.; Kaikkonen, J.; Zunft, H.-F.; et al. Elevated circulating LDL phenol levels in men who consumed virgin rather than refined olive oil are associated with less oxidation of plasma LDL. J. Nutr. 2010, 140, 501-508. [CrossRef] [PubMed]

33. Mataix, J.; Quiles, J.L.; Huertas, J.R.; Battino, M.; Mañas, M. Tissue specific interactions of exercise, dietary fatty acids, and vitamin E in lipid peroxidation. Free Radic. Biol. Med. 1998, 24, 511-521. [CrossRef]

34. Conde, C.; Delrot, S.; Gerós, H. Physiological, biochemical and molecular changes occurring during olive development and ripening. J. Plant Physiol. 2008, 165, 1545-1562. [CrossRef] [PubMed]

35. Tripoli, E.; Giammanco, M.; Tabacchi, G.; Di Majo, D.; Giammanco, S.; La Guardia, M. The phenolic compounds of olive oil: Structure, biological activity and beneficial effects on human health. Nutr. Res. Rev. 2005, 18, 98-112. [CrossRef] [PubMed]

36. Aiello, A.; Guccione, G.D.; Accardi, G.; Caruso, C. What olive oil for healthy ageing? Maturitas 2015, 80, 117-118. [CrossRef] [PubMed]

37. Servili, M.; Selvaggini, R.; Esposto, S.; Taticchi, A.; Montedoro, G.; Morozzi, G. Health and sensory properties of virgin olive oil hydrophilic phenols: Agronomic and technological aspects of production that affect their occurrence in the oil. J. Chromatogr. A 2004, 1054, 113-127. [CrossRef]

38. Servili, M.; Esposto, S.; Lodolini, E.; Selvaggini, R.; Taticchi, A.; Urbani, S.; Montedoro, G.; Serravalle, M.; Gucci, R. Irrigation effects on quality, phenolic composition, and selected volatiles of virgin olive oils cv. Leccino. J. Agric. Food Chem. 2007, 55, 6609-6618. [CrossRef] [PubMed]

39. Commission Implementing Regulation (EU) 2015/1833 of 12 October 2015 Amending Regulation (EEC) No 2568/91 on the Characteristics of Olive Oil and Olive-Residue Oil and on the Relevant Methods of Analysis. Available online: https:/ / eur-lex.europa.eu/legal-content/EN/TXT/?uri=uriserv:OJ.L_.2015.266.01.0029. 01.ENG\&toc=OJ:L:2015:266:TOC (accessed on 1 July 2018).

40. Perdomo, L.; Beneit, N.; Otero, Y.F.; Escribano, Ó.; Díaz-Castroverde, S.; Gómez-Hernández, A.; Benito, M. Protective role of oleic acid against cardiovascular insulin resistance and in the early and late cellular atherosclerotic process. Cardiovasc. Diabetol. 2015, 14, 75. [CrossRef] [PubMed]

41. Visioli, F.; Galli, C. Biological properties of olive oil phytochemicals. Crit. Rev. Food Sci. Nutr. 2002, 42, 209-221. [CrossRef] [PubMed]

42. Covas, M.-I.; Nyyssönen, K.; Poulsen, H.E.; Kaikkonen, J.; Zunft, H.-J.F.; Kiesewetter, H.; Gaddi, A.; de la Torre, R.; Mursu, J.; Bäumler, H.; et al. The effect of polyphenols in olive oil on heart disease risk factors: A randomized trial. Ann. Intern. Med. 2006, 145, 333-341. [CrossRef] [PubMed]

43. Nicolaïew, N.; Lemort, N.; Adorni, L.; Berra, B.; Montorfano, G.; Rapelli, S.; Cortesi, N.; Jacotot, B. Comparison between extra virgin olive oil and oleic acid rich sunflower oil: Effects on postprandial lipemia and LDL susceptibility to oxidation. Ann. Nutr. Metab. 1998, 42, 251-260. [CrossRef] [PubMed]

44. Carluccio, M.A.; Siculella, L.; Ancora, M.A.; Massaro, M.; Scoditti, E.; Storelli, C.; Visioli, F.; Distante, A.; De Caterina, R. Olive oil and red wine antioxidant polyphenols inhibit endothelial activation: Antiatherogenic properties of Mediterranean diet phytochemicals. Arterioscler. Thromb. Vasc. Biol. 2003, 23, 622-629. [CrossRef] [PubMed]

45. Cicerale, S.; Lucas, L.J.; Keast, R.S.J. Antimicrobial, antioxidant and anti-inflammatory phenolic activities in extra virgin olive oil. Curr. Opin. Biotechnol. 2012, 23, 129-135. [CrossRef] [PubMed] 
46. Montedoro, G.; Servili, M.; Baldioli, M.; Miniati, E. Simple and hydrolyzable phenolic compounds in virgin olive oil. 1. Their extraction, separation, and quantitative and semiquantitative evaluation by HPLC. J. Agric. Food Chem. 1992, 40, 1571-1576. [CrossRef]

47. Galli, C.; Visioli, F. Antioxidant and other activities of phenolics in olives/olive oil, typical components of the Mediterranean diet. Lipids 1999, 34, S23-S26. [CrossRef] [PubMed]

48. Caponio, F.; Bilancia, M.T.; Pasqualone, A.; Sikorska, E.; Gomes, T. Influence of the exposure to light on extra virgin olive oil quality during storage. Eur. Food Res. Technol. 2005, 221, 92-98. [CrossRef]

49. Caponio, F.; Squeo, G.; Brunetti, L.; Pasqualone, A.; Summo, C.; Paradiso, V.M.; Catalano, P.; Bianchi, B. Influence of the feed pipe position of an industrial scale two-phase decanter on extraction efficiency and chemical-sensory characteristics of virgin olive oil. J. Sci. Food Agric. 2018, 98, 4279-4286. [CrossRef] [PubMed]

50. Difonzo, G.; Russo, A.; Trani, A.; Paradiso, V.M.; Ranieri, M.; Pasqualone, A.; Summo, C.; Tamma, G.; Silletti, R.; Caponio, F. Green extracts from Coratina olive cultivar leaves: Antioxidant characterization and biological activity. J. Funct. Foods 2017, 31, 63-70. [CrossRef]

51. Squeo, G.; Tamborrino, A.; Pasqualone, A.; Leone, A.; Paradiso, V.M.; Summo, C.; Caponio, F. Assessment of the Influence of the Decanter Set-up During Continuous Processing of Olives at Different Pigmentation Index. Food Bioprocesss Technol. 2017, 10, 592-602. [CrossRef]

52. Squeo, G.; Silletti, R.; Summo, C.; Paradiso, V.M.; Pasqualone, A.; Caponio, F. Influence of calcium carbonate on extraction yield and quality of extra virgin oil from olive (Olea europaea L. cv. Coratina). Food Chem. 2016, 209, 65-71. [CrossRef] [PubMed]

53. Terés, S.; Barceló-Coblijn, G.; Benet, M.; Alvarez, R.; Bressani, R.; Halver, J.E.; Escribá, P.V. Oleic acid content is responsible for the reduction in blood pressure induced by olive oil. Proc. Natl. Acad. Sci. USA 2008, 105, 13811-13816. [CrossRef] [PubMed]

54. Poole, S.; Blades, M. The Mediterranean diet-A review of evidence relevant to the food and drink industry. Nutr. Food Sci. 2013, 43, 7-16. [CrossRef]

55. Makedou, K.; Papandreou, D.; Karampola, M. The role of Mediterranean diet in health and disease: An updated mini review. Nutr. Food Sci. 2011, 41, 63-72. [CrossRef]

56. EFSA Panel on Dietetic Products Nutrition and Allergens. Scientific Opinion on the substantiation of health claims related to polyphenols in olive and protection of LDL particles from oxidative damage (ID 1333, 1638 1639,1696 , 2865), maintenance of normal blood HDL cholesterol concentrations (ID 1639), maintenance of normal blood pressure (ID 3781), "anti-inflammatory properties" (ID 1882), "contributes to the upper respiratory tract health" (ID 3468), "can help to maintain a normal function of gastrointestinal tract"(3779), and "contributes to body defenses against external agents" (ID 3467) pursuant to Article 13(1) of Regulation (EC) No 1924/2006. EFSA J. 2011, 9, 2033-2058.

57. Commission Regulation (EU) No 432/2012 of 16 May 2012 Establishing a List of Permitted Health Claims Made on Foods, Other than Those Referring to the Reduction of Disease Risk and to Children's Development and Health. Available online: https://eur-lex.europa.eu/legal-content/EN/ALL/?uri= CELEX\%3A32012R0432 (accessed on 1 July 2018).

58. DeFelice, S.L. The nutraceutical revolution: Its impact on food industry R\&D. Trends Food Sci. Technol. 1995, 6, 59-61. [CrossRef]

59. Marinelli, N.; Scozzafava, G.; Romano, C.; Contini, C.; Casini, L. Nutraceutical olive oil: Does it make the difference? Nutr. Food Sci. 2014, 44, 586-600. [CrossRef]

60. Visioli, F.; Galli, C.; Bornet, F.; Mattei, A.; Patelli, R.; Galli, G.; Caruso, D. Olive oil phenolics are dose-dependently absorbed in humans. FEBS Lett. 2000, 468, 159-160. [CrossRef]

61. Tuck, K.L.; Hayball, P.J. Major phenolic compounds in olive oil: Metabolism and health effects. J. Nutr. Biochem. 2002, 13, 636-644. [CrossRef]

62. Vissers, M.N.; Zock, P.L.; Roodenburg, A.J.C.; Leenen, R.; Katan, M.B. Olive oil phenols are absorbed in humans. J. Nutr. 2002, 132, 409-417. [CrossRef] [PubMed]

63. Keceli, T.M.; Kamiloglu, S.; Capanoglu, E. Phenolic Compounds of Olives and Olive Oil and their Bioavailability. In Olives and Olive Oil as Functional Foods: Bioactivity, Chemistry and Processing; Shahidi, F., Kiritsakis, A., Eds.; John Wiley \& Sons Ltd.: Hoboken, NJ, USA, 2017; Chapter 24; pp. 457-470.

64. Caruso, D.; Visioli, F.; Patelli, R.; Galli, C.; Galli, G. Urinary excretion of olive oil phenols and their metabolites in humans. Metabolism 2001, 50, 1426-1428. [CrossRef] [PubMed] 
65. Weinbrenner, T.; Fito, M.; Farre, A.M.; Saez, G.T.; Rijken, P.; Tormos, C.; Coolen, S.; De la Torre, R.; Covas, M.I. Bioavailability of phenolic compounds from olive oil and oxidative/antioxidant status at postprandial state in healthy humans. Drugs Exp. Clin. Res. 2003, 30, 207-212.

66. Covas, M.I.; De la Torre, K.; Farre-Albaladejo, M.; Kaikkonen, J.; Fito, M.; Lopez-Sabater, C.; Pujadas-Bastardes, M.A.; Joglar, J.; Weinbrenner, T.; Lamuela-Raventos, R.M.; et al. Postprandial LDL phenolic content and LDL oxidation are modulated by olive oil phenolic compounds in humans. Free Radic. Biol. Med. 2006, 40, 608-616. [CrossRef] [PubMed]

67. Miro-Casas, E.; Covas, M.I.; Farre, M.; Fito, M.; Ortuno, J.; Weinbrenner, T.; Roset, P.; de la Torre, R. Hydroxytyrosol disposition in humans. Clin. Chem. 2003, 49, 945-952. [CrossRef] [PubMed]

68. Tsimidou, M. Polyphenols and Quality of Virgin Olive Oil in Retrospect. Ital. J. Food Sci. 1998, 10, 99-116.

69. Gutfinger, T. Polyphenols in olive oils. J. Am. Oil Chem. Soc. 1991, 58, 966-968. [CrossRef]

70. Krichene, D.; Salvador, M.D.; Fregapane, G. Stability of Virgin Olive Oil Phenolic Compounds during Long-Term Storage (18 Months) at Temperatures of 5-50 ${ }^{\circ}$ C. J. Agric. Food Chem. 2015, 63, 6779-6786. [CrossRef] [PubMed]

71. Sun, L.; Luo, C.; Liu, J. Hydroxytyrosol induces apoptosis in human colon cancer cells through ROS generation. Food Funct. 2014, 5, 1909-1914. [CrossRef] [PubMed]

72. Li, S.; Han, Z.; Ma, Y.; Song, R.; Pei, T.; Zheng, T.; Wang, J.; Xu, D.; Fang, X.; Jiang, H.; et al. Hydroxytyrosol inhibits cholangiocarcinoma tumor growth: An in vivo and in vitro study. Oncol. Rep. 2014, 31, 145-152. [CrossRef] [PubMed]

73. Zhao, B.; Ma, Y.; Xu, Z.; Wang, J.; Wang, F.; Wang, D.; Pan, S.; Wu, Y.; Pan, H.; Xu, D.; et al. Hydroxytyrosol, a natural molecule from olive oil, suppresses the growth of human hepatocellular carcinoma cells via inactivating AKT and nuclear factor-kappa B pathways. Cancer Lett. 2014, 347, 79-87. [CrossRef] [PubMed]

74. Rosignoli, P.; Fuccelli, R.; Sepporta, M.V.; Fabiani, R. In vitro chemo-preventive activities of hydroxytyrosol: The main phenolic compound present in extra-virgin olive oil. Food Funct. 2016, 7, 301-307. [CrossRef] [PubMed]

75. Toteda, G.; Lupinacci, S.; Vizza, D.; Bonofiglio, R.; Perri, E.; Bonofiglio, M.; Lofaro, D.; La Russa, A.; Leone, F.; Gigliotti, P.; et al. High doses of hydroxytyrosol induce apoptosis in papillary and follicular thyroid cancer cells. J. Endocrinol. Investig. 2017, 40, 153-162. [CrossRef] [PubMed]

76. López de Las Hazas, M.-C.; Piñol, C.; Macià, A.; Motilva, M.-J. Hydroxytyrosol and the Colonic Metabolites Derived from Virgin Olive Oil Intake Induce Cell Cycle Arrest and Apoptosis in Colon Cancer Cells. J. Agric. Food Chem. 2017, 65, 6467-6476. [CrossRef] [PubMed]

77. Lamy, S.; Ouanouki, A.; Béliveau, R.; Desrosiers, R.R. Olive oil compounds inhibit vascular endothelial growth factor receptor-2 phosphorylation. Exp. Cell Res. 2014, 322, 89-98. [CrossRef] [PubMed]

78. Granados-Principal, S.; Quiles, J.L.; Ramirez-Tortosa, C.; Camacho-Corencia, P.; Sanchez-Rovira, P.; Vera-Ramirez, L.; Ramirez-Tortosa, M. Hydroxytyrosol inhibits growth and cell proliferation and promotes high expression of sfrp4 in rat mammary tumours. Mol. Nutr. Food Res. 2011, 55, S117-S126. [CrossRef] [PubMed]

79. Di Francesco, A.; Falconi, A.; Di Germanio, C.; Micioni Di Bonaventura, M.V.; Costa, A.; Caramuta, S.; Del Carlo, M.; Compagnone, D.; Dainese, E.; Cifani, C.; et al. Extravirgin olive oil up-regulates $\mathrm{CB}_{1}$ tumor suppressor gene in human colon cancer cells and in rat colon via epigenetic mechanisms. J. Nutr. Biochem. 2015, 26, 250-258. [CrossRef] [PubMed]

80. Zhang, X.; Cao, J.; Zhong, L. Hydroxytyrosol inhibits pro-inflammatory cytokines, iNOS, and COX-2 expression in human monocytic cells. Naunyn Schmiedeberg's Arch. Pharmacol. 2009, 379, 581-586. [CrossRef] [PubMed]

81. Gong, D.; Geng, C.; Jiang, L.; Cao, J.; Yoshimura, H.; Zhong, L. Effects of hydroxytyrosol-20 on carrageenan-induced acute inflammation and hyperalgesia in rats. Phytother. Res. 2009, 23, 646-650. [CrossRef] [PubMed]

82. Scoditti, E.; Calabriso, N.; Massaro, M.; Pellegrino, M.; Storelli, C.; Martines, G.; De Caterina, R.; Carluccio, M.A. Mediterranean diet polyphenols reduce inflammatory angiogenesis through MMP-9 and COX-2 inhibition in human vascular endothelial cells: A potentially protective mechanism in atherosclerotic vascular disease and cancer. Arch. Biochem. Biophys. 2012, 527, 81-89. [CrossRef] [PubMed] 
83. Scoditti, E.; Nestola, A.; Massaro, M.; Calabriso, N.; Storelli, C.; De Caterina, R.; Carluccio, M.A. Hydroxytyrosol suppresses MMP-9 and COX-2 activity and expression in activated human monocytes via PKC $\alpha$ and PKC $\beta 1$ inhibition. Atherosclerosis 2014, 232, 17-24. [CrossRef] [PubMed]

84. Giordano, E.; Dávalos, A.; Visioli, F. Chronic hydroxytyrosol feeding modulates glutathione-mediated oxido-reduction pathways in adipose tissue: A nutrigenomic study. Nutr. Metab. Cardiovasc. Dis. 2014, 24, 1144-1150. [CrossRef] [PubMed]

85. Venturi, F.; Sanmartin, C.; Taglieri, I.; Nari, A.; Andrich, G.; Terzuoli, E.; Donnini, S.; Nicolella, C.; Zinnai, A. Development of phenol-enriched olive oil with phenolic compounds extracted from wastewater produced by physical refining. Nutrients 2017, 9, 916. [CrossRef] [PubMed]

86. Burattini, S.; Salucci, S.; Baldassarri, V.; Accorsi, A.; Piatti, E.; Madrona, A.; Espartero, J.L.; Candiracci, M.; Zappia, G.; Falcieri, E. Anti-apoptotic activity of hydroxytyrosol and hydroxytyrosyl laurate. Food Chem. Toxicol. 2013, 55, 248-256. [CrossRef] [PubMed]

87. Storniolo, C.E.; Roselló-Catafau, J.; Pintó, X.; Mitjavila, M.T.; Moreno, J.J. Polyphenol fraction of extra virgin olive oil protects against endothelial dysfunction induced by high glucose and free fatty acids through modulation of nitric oxide and endothelin-1. Redox Biol. 2014, 2, 971-977. [CrossRef] [PubMed]

88. Mateos, R.; Martínez-López, S.; Baeza Arévalo, G.; Amigo-Benavent, M.; Sarriá, B.; Bravo-Clemente, L. Hydroxytyrosol in functional hydroxytyrosol-enriched biscuits is highly bioavailable and decreases oxidised low density lipoprotein levels in humans. Food Chem. 2016, 205, 248-256. [CrossRef] [PubMed]

89. Lopez-Huertas, E.; Fonolla, J. Hydroxytyrosol supplementation increases vitamin C levels in vivo. A human volunteer trial. Redox Biol. 2017, 11, 384-389. [CrossRef] [PubMed]

90. Giordano, E.; Dangles, O.; Rakotomanomana, N.; Baracchini, S.; Visioli, F. 3-O-Hydroxytyrosol glucuronide and 4-O-hydroxytyrosol glucuronide reduce endoplasmic reticulum stress in vitro. Food Funct. 2015, 6, 3275-3281. [CrossRef] [PubMed]

91. Ruano, J.; López-Miranda, J.; de la Torre, R.; Delgado-Lista, J.; Fernández, J.; Caballero, J.; Covas, M.I.; Jiménez, Y.; Pérez-Martínez, P.; Marín, C.; et al. Intake of phenol-rich virgin olive oil improves the postprandial prothrombotic profile in hypercholesterolemic patients. Am. J. Clin. Nutr. 2007, 86, 341-346. [CrossRef] [PubMed]

92. Minamino, T.; Kitakaze, M. ER stress in cardiovascular disease. J. Mol. Cell. Cardiol. 2010, 48, 1105-1110. [CrossRef] [PubMed]

93. Visioli, F.; Bernardini, E. Extra virgin olive oil's polyphenols: Biological activities. Curr. Pharm. Des. 2011, 17, 786-804. [CrossRef] [PubMed]

94. Miró-Casas, E.; Covas, M.-I.; Fitó, M.; Farré-Albadalejo, M.; Marrugat, J.; de la Torre, R. Tyrosol and hydroxytyrosol are absorbed from moderate and sustained doses of virgin olive oil in humans. Eur. J. Clin. Nutr. 2003, 57, 186-190. [CrossRef] [PubMed]

95. Beauchamp, G.K.; Keast, R.S.J.; Morel, D.; Lin, J.; Pika, J.; Han, Q.; Lee, C.-H.; Smith, A.B.; Breslin, P.A.S. Phytochemistry: Ibuprofen-like activity in extra-virgin olive oil. Nature 2005, 437, 45-46. [CrossRef] [PubMed]

96. Smith, A.B.; Han, Q.; Breslin, P.A.S.; Beauchamp, G.K. Synthesis and assignment of absolute configuration of (-)-oleocanthal: A potent, naturally occurring non-steroidal anti-inflammatory and anti-oxidant agent derived from extra virgin olive oils. Org. Lett. 2005, 7, 5075-5078. [CrossRef] [PubMed]

97. Iacono, A.; Gómez, R.; Sperry, J.; Conde, J.; Bianco, G.; Meli, R.; Gómez-Reino, J.J.; Smith, A.B.; Gualillo, O. Effect of oleocanthal and its derivatives on inflammatory response induced by lipopolysaccharide in a murine chondrocyte cell line. Arthritis Rheum. 2010, 62, 1675-1682. [CrossRef] [PubMed]

98. Khanal, P.; Oh, W.-K.; Yun, H.J.; Namgoong, G.M.; Ahn, S.-G.; Kwon, S.-M.; Choi, H.-K.; Choi, H.S. p-HPEA-EDA, a phenolic compound of virgin olive oil, activates AMP-activated protein kinase to inhibit carcinogenesis. Carcinogenesis 2011, 32, 545-553. [CrossRef] [PubMed]

99. Romero, C.; Medina, E.; Vargas, J.; Brenes, M.; De Castro, A. In vitro activity of olive oil polyphenols against Helicobacter pylori. J. Agric. Food Chem. 2007, 55, 680-686. [CrossRef] [PubMed]

100. Akl, M.R.; Ayoub, N.M.; Mohyeldin, M.M.; Busnena, B.A.; Foudah, A.I.; Liu, Y.-Y.; Sayed, K.A.E. Olive Phenolics as c-Met Inhibitors: (-)-Oleocanthal Attenuates Cell Proliferation, Invasiveness, and Tumor Growth in Breast Cancer Models. PLoS ONE 2014, 9, e97622. [CrossRef] [PubMed] 
101. Pei, T.; Meng, Q.; Han, J.; Sun, H.; Li, L.; Song, R.; Sun, B.; Pan, S.; Liang, D.; Liu, L. (-)-Oleocanthal inhibits growth and metastasis by blocking activation of STAT3 in human hepatocellular carcinoma. Oncotarget 2016, 7, 43475-43491. [CrossRef] [PubMed]

102. LeGendre, O.; Breslin, P.A.; Foster, D.A. (-)-Oleocanthal rapidly and selectively induces cancer cell death via lysosomal membrane permeabilization. Mol. Cell. Oncol. 2015, 2, e1006077. [CrossRef] [PubMed]

103. Khanfar, M.A.; Bardaweel, S.K.; Akl, M.R.; El Sayed, K.A. Olive Oil-derived Oleocanthal as Potent Inhibitor of Mammalian Target of Rapamycin: Biological Evaluation and Molecular Modeling Studies. Phytother. Res. 2015, 29, 1776-1782. [CrossRef] [PubMed]

104. Ayoub, N.M.; Siddique, A.B.; Ebrahim, H.Y.; Mohyeldin, M.M.; El Sayed, K.A. The olive oil phenolic (-)-oleocanthal modulates estrogen receptor expression in luminal breast cancer in vitro and in vivo and synergizes with tamoxifen treatment. Eur. J. Pharmacol. 2017, 810, 100-111. [CrossRef] [PubMed]

105. Sepporta, M.V.; Fuccelli, R.; Rosignoli, P.; Ricci, G.; Servili, M.; Fabiani, R. Oleuropein Prevents Azoxymethane-Induced Colon Crypt Dysplasia and Leukocytes DNA Damage in A/J Mice. J. Med. Food 2016, 19, 983-989. [CrossRef] [PubMed]

106. Hassan, Z.K.; Elamin, M.H.; Omer, S.A.; Daghestani, M.H.; Al-Olayan, E.S.; Elobeid, M.A.; Virk, P. Oleuropein induces apoptosis via the p53 pathway in breast cancer cells. Asian Pac. J. Cancer Prev. 2014, 14, 6739-6742. [CrossRef] [PubMed]

107. Bulotta, S.; Corradino, R.; Celano, M.; Maiuolo, J.; D’Agostino, M.; Oliverio, M.; Procopio, A.; Filetti, S.; Russo, D. Antioxidant and antigrowth action of peracetylated oleuropein in thyroid cancer cells. J. Mol. Endocrinol. 2013, 51, 181-189. [CrossRef] [PubMed]

108. Cárdeno, A.; Sánchez-Hidalgo, M.; Rosillo, M.A.; Alarcón de la Lastra, C. Oleuropein, a secoiridoid derived from olive tree, inhibits the proliferation of human colorectal cancer cell through downregulation of HIF- $1 \alpha$. Nutr. Cancer 2013, 65, 147-156. [CrossRef] [PubMed]

109. Yan, C.-M.; Chai, E.-Q.; Cai, H.-Y.; Miao, G.-Y.; Ma, W. Oleuropein induces apoptosis via activation of caspases and suppression of phosphatidylinositol 3-kinase/protein kinase B pathway in HepG2 human hepatoma cell line. Mol. Med. Rep. 2015, 11, 4617-4624. [CrossRef] [PubMed]

110. Leri, M.; Nosi, D.; Natalello, A.; Porcari, R.; Ramazzotti, M.; Chiti, F.; Bellotti, V.; Doglia, S.M.; Stefani, M.; Bucciantini, M. The polyphenol Oleuropein aglycone hinders the growth of toxic transthyretin amyloid assemblies. J. Nutr. Biochem. 2016, 30, 153-166. [CrossRef] [PubMed]

111. Bendini, A.; Cerretani, L.; Carrasco-Pancorbo, A.; Gómez-Caravaca, A.M.; Segura-Carretero, A.; Fernández-Gutiérrez, A.; Lercker, G. Phenolic molecules in virgin olive oils: A survey of their sensory properties, health effects, antioxidant activity and analytical methods. An overview of the last decade. Molecules 2007, 12, 1679-1719. [CrossRef] [PubMed]

112. Impellizzeri, D.; Esposito, E.; Mazzon, E.; Paterniti, I.; Di Paola, R.; Bramanti, P.; Morittu, V.M.; Procopio, A.; Britti, D.; Cuzzocrea, S. The effects of oleuropein aglycone, an olive oil compound, in a mouse model of carrageenan-induced pleurisy. Clin. Nutr. 2011, 30, 533-540. [CrossRef] [PubMed]

113. Dell'Agli, M.; Fagnani, R.; Galli, G.V.; Maschi, O.; Gilardi, F.; Bellosta, S.; Crestani, M.; Bosisio, E.; De Fabiani, E.; Caruso, D. Olive oil phenols modulate the expression of metalloproteinase 9 in THP-1 cells by acting on nuclear factor-kappaB signaling. J. Agric. Food Chem. 2010, 58, 2246-2252. [CrossRef] [PubMed]

114. Sánchez-Quesada, C.; López-Biedma, A.; Gaforio, J.J. Oleanolic Acid, a Compound Present in Grapes and Olives, Protects against Genotoxicity in Human Mammary Epithelial Cells. Molecules 2015, 20, 13670-13688. [CrossRef] [PubMed]

115. Sánchez-Quesada, C.; López-Biedma, A.; Gaforio, J.J. The differential localization of a methyl group confers a different anti-breast cancer activity to two triterpenes present in olives. Food Funct. 2015, 6, 249-256. [CrossRef] [PubMed]

116. Corominas-Faja, B.; Cuyàs, E.; Lozano-Sánchez, J.; Cufí, S.; Verdura, S.; Fernández-Arroyo, S.; Borrás-Linares, I.; Martin-Castillo, B.; Martin, Á.G.; Lupu, R.; et al. Extra-virgin olive oil contains a metabolo-epigenetic inhibitor of cancer stem cells. Carcinogenesis 2018, 39, 601-613. [CrossRef] [PubMed]

117. Allouche, Y.; Warleta, F.; Campos, M.; Sánchez-Quesada, C.; Uceda, M.; Beltrán, G.; Gaforio, J.J. Antioxidant, antiproliferative, and pro-apoptotic capacities of pentacyclic triterpenes found in the skin of olives on MCF-7 human breast cancer cells and their effects on DNA damage. J. Agric. Food Chem. 2011, 59, 121-130. [CrossRef] [PubMed] 
118. Warleta, F.; Quesada, C.S.; Campos, M.; Allouche, Y.; Beltrán, G.; Gaforio, J.J. Hydroxytyrosol protects against oxidative DNA damage in human breast cells. Nutrients 2011, 3, 839-857. [CrossRef] [PubMed]

119. Warleta, F.; Campos, M.; Allouche, Y.; Sánchez-Quesada, C.; Ruiz-Mora, J.; Beltrán, G.; Gaforio, J.J. Squalene protects against oxidative DNA damage in MCF10A human mammary epithelial cells but not in MCF7 and MDA-MB-231 human breast cancer cells. Food Chem. Toxicol. 2010, 48, 1092-1100. [CrossRef] [PubMed]

120. Park, S.Y.; Nho, C.W.; Kwon, D.Y.; Kang, Y.-H.; Lee, K.W.; Park, J.H.Y. Maslinic acid inhibits the metastatic capacity of DU145 human prostate cancer cells: Possible mediation via hypoxia-inducible factor- $1 \alpha$ signalling. Br. J. Nutr. 2013, 109, 210-222. [CrossRef] [PubMed]

121. Wang, X.; Bai, H.; Zhang, X.; Liu, J.; Cao, P.; Liao, N.; Zhang, W.; Wang, Z.; Hai, C. Inhibitory effect of oleanolic acid on hepatocellular carcinoma via ERK-p53-mediated cell cycle arrest and mitochondrial-dependent apoptosis. Carcinogenesis 2013, 34, 1323-1330. [CrossRef] [PubMed]

122. Wei, J.; Liu, M.; Liu, H.; Wang, H.; Wang, F.; Zhang, Y.; Han, L.; Lin, X. Oleanolic acid arrests cell cycle and induces apoptosis via ROS-mediated mitochondrial depolarization and lysosomal membrane permeabilization in human pancreatic cancer cells. J. Appl. Toxicol. 2013, 33, 756-765. [CrossRef] [PubMed]

123. Rufino-Palomares, E.E.; Reyes-Zurita, F.J.; García-Salguero, L.; Mokhtari, K.; Medina, P.P.; Lupiáñez, J.A.; Peragón, J. Maslinic acid, a triterpenic anti-tumoural agent, interferes with cytoskeleton protein expression in HT29 human colon-cancer cells. J. Proteom. 2013, 83, 15-25. [CrossRef] [PubMed]

124. Sánchez-Tena, S.; Reyes-Zurita, F.J.; Díaz-Moralli, S.; Vinardell, M.P.; Reed, M.; García-García, F.; Dopazo, J.; Lupiáñez, J.A.; Günther, U.; Cascante, M. Maslinic acid-enriched diet decreases intestinal tumorigenesis in Apc(Min/+) mice through transcriptomic and metabolomic reprogramming. PLoS ONE 2013, 8, e59392. [CrossRef] [PubMed]

125. Es-Saady, D.; Najid, A.; Simon, A.; Denizot, Y.; Chulia, A.J.; Delage, C. Effects of ursolic acid and its analogues on soybean 15-Lipoxygenase Activity and the proliferation rate of a human gastric tumour cell line. Mediat. Inflamm. 1994, 3, 181-184. [CrossRef] [PubMed]

126. Juan, M.E.; Wenzel, U.; Daniel, H.; Planas, J.M. Erythrodiol, a natural triterpenoid from olives, has antiproliferative and apoptotic activity in HT-29 human adenocarcinoma cells. Mol. Nutr. Food Res. 2008, 52, 595-599. [CrossRef] [PubMed]

127. Martín, R.; Ibeas, E.; Carvalho-Tavares, J.; Hernández, M.; Ruiz-Gutierrez, V.; Nieto, M.L. Natural triterpenic diols promote apoptosis in astrocytoma cells through ROS-mediated mitochondrial depolarization and JNK activation. PLoS ONE 2009, 4, e5975. [CrossRef] [PubMed] 